\title{
Oak canopy arthropod communities: which factors shape its structure?
}

\author{
Leticia Valencia-Cuevas and Efraín Tovar-Sánchez
}

\begin{abstract}
Canopy of forest ecosystems has been recognized as a habitat that supports a wide variety of plants, vertebrates, invertebrates, and microbes. Within the invertebrate group, arthropods are characterized by their great abundance, diversity, and functional importance. Particularly in temperate forests, species of the genus Quercus (oaks) are one of the most important tree canopy groups, for its diversity and dominance. Different studies have shown that the oak canopy contains a high diversity of arthropods suggesting their importance as habitat for this group of organisms. In this review, we investigated the factors that determine the establishment, organization, and maintenance of arthropod communities in the oak canopy. In general, it was found that there is a lack of literature that addresses the study of oak canopy arthropod communities. Also, the following patterns were found: (a) the research has covered a wide variety of topics; however, there are differences in the depth to which each topic has been analyzed, (b) there are ambiguous criteria to define the structure of the canopy, (c) groups with different habitat preferences belonging to different guilds and uneven development stages have been studied, avoiding generalizations about patterns found, (d) the standardization in sampling techniques and collection has been difficult, (e) bias exists towards the study of phytophagous insects belonging to the Coleoptera, Hymenoptera, and Lepidoptera orders, and (f) there are few studies in other groups of arthropods, for example, acorn borers, whose activity has an impact on the fitness and dispersion of the host plants. Finally, we propose that the detection and study of patterns in oak canopy communities can be of great value to propose management and conservation strategies in these forests.
\end{abstract}

Keywords: Quercus; Temperate forests; Species diversity; Conservation

\section{Introduction}

The study of forest canopies has evolved from a new line of research into a fascinating discipline that has changed the way we perceive forest ecosystems (Nadkarni 2001; Nadkarni et al. 2004). Historically, studies in forest canopies were limited by access techniques and collection methods (Nadkarni 1994; Sutton 2001). The standardization of new access and collection methods started in the 1970s; from studies of only descriptive interest, researchers started to investigate the distribution, abundance and biodiversity of organisms, structure and functioning of the associated communities, and the dynamics of the ecosystems (Nadkarni and Parker 1994; Mitchell 2001; Stork et al. 2008). As access (i.e., balloons, cranes, platforms, bridges) and sampling methods (i.e.,

\footnotetext{
*Correspondence: efrain_tovar@uaem.mx

Departamento de Sistemática y Evolución, Centro de Investigación en

Biodiversidad y Conservación, Universidad Autónoma del Estado de Morelos, Av. Universidad 1001, Col. Chamilpa, Cuernavaca, Morelos CP 62209, México
}

sprays, light traps, hand collecting) have evolved, canopy research became a viable option for researchers in many scientific disciplines, such as botany, zoology, landscape and ecosystem ecology, meteorology, conservation biology, etc. (Sutton 2001; Nadkarni et al. 2004; Stork 2007). This development promoted the diversification of research topics in the field, such as the study of community structure, biodiversity, choice of hosts, succession, and climate change (Lowman and Nadkarni 1995; Adis et al. 1998; Ozanne et al. 2003; Stork and Hammond 2013). Currently, canopy studies have matured, which is reflected in an increase in the number publications on cutting-edge topics. For example, the impact of global climate change and habitat disturbance on biodiversity and ecosystem dynamics is currently being assessed in the canopy of forests (Ozanne et al. 2003; Rinker and Lowman 2004; Lowman 2009) using a predictive approach.

The term "canopy" has been defined by different authors (Moffett 2000; Ozanne et al. 2003; Nadkarni et al. 2004); 
however, in this review, we use the definitions associated with forests. In general, the proposals made by different authors are integrated in the following definition: "it is the aerial part where all the foliage, buds, fine branches, associated flora and fauna, the suspended soil and the interstices (air) of a forest are combined." Depending on the type of vegetation, the canopy can be defined vertically according to the different layers of vegetation between the ground and the canopy, which gradually modulates biotic (floristic composition, leaf area, biomass density, species diversity) and abiotic parameters (temperature, humidity, sunshine, wind velocity) (Basset et al. 2003a). This stratification creates a mosaic of resources and conditions that may be occupied by different organisms.

Several studies have documented that the canopy contains most of the photosynthetically active biomass in forest ecosystems (Wright and Van Schaik 1994; Ozanne et al. 2003) and is therefore the main energy absorption site in the biosphere (Basset et al. 2003b), as well as a site in which an intensive exchange of oxygen, water vapor, and carbon dioxide takes place (Hurtado et al. 2003). Furthermore, the canopy is a habitat that supports a wide variety of organisms, including plants, arboreal vertebrates, invertebrates, and microorganisms (Nadkarni et al. 2004), a discovery that has had a significant impact on the perception of biodiversity patterns at local, regional, and global levels (Erwin 1982; Novotny et al. 2002; Basset et al. 2003b). Since the early 1980s, the arthropod community associated with canopies is the one that has received the most attention. In particular, studies have focused on taxonomically describing the species associated with canopies, as well as the ecological processes that regulate populations, communities, and ecosystems (Southwood et al. 1982; Erwin 1995; Palacios-Vargas and Castaño-Meneses 2003; TovarSánchez et al. 2013). In addition, the functional importance of arthropods in terrestrial ecosystems (pollinators, prey, parasites, parasitoids, herbivores, and detritivores) has stimulated the interest of researchers in the study of their communities (McIntyre et al. 2001). In general, the parameters that have been used to describe the structure of the canopy arthropod communities are the following: abundance, biomass, composition, richness, and diversity of species.

The results obtained by the works mentioned above indicate that the arthropod fauna associated with the canopy of temperate and tropical forests constitutes a very significant proportion of the global biodiversity (Erwin 1982; Novotny et al. 2002; Novotny and Basset 2005; Basset et al. 2007); the most recent estimate suggests 6.1 million species (Hamilton et al. 2013). In general, the diversity of arthropod species associated with the canopy is influenced by a latitudinal gradient (i.e., mites, collembola, beetles, and ants.), for example, there is greater diversity in tropical forests compared to temperate forests (Gaston 2000; Nigel and Hughes 2004; Rinker and Lowman 2004; Novotny et al. 2006), a condition that could be a response to the increasing diversity of plants in the same direction (Novotny et al. 2006). The great diversity of plants and canopy arthropods that has been reported in tropical forests, coupled with their great exuberance, could explain the fact that, historically, the study of arthropod communities associated with the canopy has focused on these forests.

In particular, studies around the world have emphasized the importance of studying the arthropod fauna associated with the canopy of temperate forests, as well as the factors that determine the structure of their communities, since it has been shown that the canopy of these forests contains unique communities with a high diversity of species (Summerville et al. 2003a,b; Sobek et al. 2008; Tovar-Sánchez et al. 2013).

Oaks (Fagaceae: Quercus) are one of most important tree and shrub groups in temperate forests; they are widely distributed worldwide (Nixon 1993), have a great diversity of species (531, Govaerts and Frodin 1998), and are dominant components of the canopy (Challenger 1998). According to the latest taxonomic classification, the genus Quercus is divided into two subgenera, Cyclobalanopsis and Quercus (Nixon 1993; Manos and Stanford 2001). In particular, the subgenus Quercus includes four sections: Cerris, Lobatae (red oaks), Protobalanus (intermediate oaks), and Quercus (white oaks).

Most works that have addressed the study of oak canopy arthropod communities have included species belonging to the commonly called "red oaks" (Lobatae, i.e., Yarnes et al. 2008; Tovar-Sánchez 2009, Tovar-Sánchez et al. 2013; Tovar-Sánchez et al. 2015a,b) and "white oaks" (Quercus, i. e., Southwood et al. 2004, 2005; Yarnes et al. 2008; Tack et al. 2010). There are few studies in oaks belonging to other groups (Southwood et al. 2004, 2005; Nazemi et al. 2008). The works mentioned above included species belonging to different geographic regions (i.e., Africa (Moran and Southwood 1982; Southwood et al. 1982), America (Preszler and Boecklen 1994; Forkner et al. 2004; Yarnes et al. 2008; Tovar-Sánchez et al. 2013), Asia (Ishida et al. 2003; Ito and Ozaki 2005; Nakamura et al. 2008), and Europe (Southwood et al. 2004, 2005; Sobek et al. 2008)]. In general, these studies have revealed a great diversity of canopy arthropods (including epiphytes and suspended soil), a pattern that suggests that oaks are important habitats for these organisms.

Therefore, this paper aims to review the different factors that contribute to the establishment, organization, and maintenance of arthropod communities associated with the canopy of oaks. The following paragraphs describe and discuss the factors affecting this structure, 
the patterns found, and the implications on the diversity and conservation of oak forests. The depth with which each topic is covered depends on the number of publications that support it.

\section{Review}

Genetic diversity of the host plant

Genetic diversity can be defined as any measurement that quantifies the magnitude of genetic variability at the individual, population, or species level (Nason 2002; Hughes et al. 2008). Genetic diversity has been considered the raw material for evolution by natural selection (Fisher 1930) and a fundamental source of biodiversity (Hughes et al. 2008). In general, its ecological consequences at the population level have been well studied (i.e., greater fitness of the population and lower risk of extinction, Vellend and Geber 2005). However, the role of genetic diversity in the organization and dynamics of communities is not yet clear (Johnson and Stinchcombe 2007; Hersch-Green et al. 2011; Wymore et al. 2011). It has been proposed that for genetic diversity to have a significant impact on a community, the latter must be dominated by one or a few foundation species (Bangert and Whitham 2007; Hughes et al. 2008). Foundation species are those that define and structure communities by creating locally stable conditions and providing resources for other species, besides participating in the modulation and stabilization of ecosystem processes (Ellison et al. 2005; Whitham et al. 2006). The trees of forest ecosystems are excellent candidates for foundation species because their architectural, functional, and physiological characteristics define the structure of the forests and can influence the microclimate, and their biomass and chemical constitution contribute significantly to ecosystem processes (Ellison et al. 2005). However, not only the trees of temperate zones have attributes of foundation species; tropical trees, seagrass, alpine herbs, coastal scrub, terrestrial grasses, and ferns have also been considered foundation species within their ecosystems (Whitham et al. 2012).

To date, most studies that have shown a genetic basis of variation in the phenotype of a community have been conducted in hybrid plants (i.e., Eucalyptus, Dungey et al. 2000; Salix, Hochwender and Fritz 2004; Quercus, TovarSánchez and Oyama 2006b) and in specific genotypes within a species (i.e., Oenothera, Johnson and Agrawal 2005; Populus, Shuster et al. 2006, Schweitzer et al. 2008; Solidago, Crutsinger et al. 2008). In contrast, few studies have assessed a parameter of genetic diversity with respect to a parameter of community structure (i.e., Populus, Wimp et al. 2004; Quercus, Tovar-Sánchez and Oyama 2006 b, Tovar-Sánchez et al. 2013). One of the groups of herbivorous insects most commonly used in these studies are endophagous insects, probably due to their high degree of specialization and their close relationship with the host plants (Tovar-Sánchez and Oyama 2006b). However, it is important to mention that communities of endophytic fungi, mycorrhizae, epiphytic and terrestrial plants, and soil microorganisms have also responded significantly to plant genetics (Whitham et al. 2012).

In particular, the effect of the genetic diversity of host species on arthropod communities associated with the canopy has been analyzed in terms of composition (Dungey et al. 2000; Bangert et al. 2005; Wimp et al. 2005; Bailey et al. 2006), richness (Dungey et al. 2000; Bangert et al. 2005, 2006, 2008), relative abundance (McIntyre and Whitham 2003; Wimp et al. 2005), and diversity of species (Wimp et al. 2004; Tovar-Sánchez and Oyama 2006b; Tovar-Sánchez et al. 2013). In general, the following patterns have been detected: (1) the diversity of arthropod communities is positively and significantly related to the genetic diversity of host species (Wimp et al. 2004; Tovar-Sánchez and Oyama 2006a; Tovar-Sánchez et al. 2013); (2) genetically more similar hosts support more similar associated arthropod communities (Bangert et al. 2006; Bangert and Whitham 2007; Kiers et al. 2010). In the first case, it has been proposed that increasing the genetic diversity of the host plant can generate changes in its morphological (Lambert et al. 1995; González-Rodríguez et al. 2004; Tovar-Sánchez and Oyama 2004), phenological (Hunter et al. 1997), architectural (Martinsen and Whitham 1994; Whitham et al. 1999; Bangert et al. 2005), and chemical characteristics (Fritz 1999; Cheng et al. 2011). These changes can be translated into a broader mosaic of resources and conditions that can be used by canopy arthropods. In the second case, it has been suggested that more genetically similar populations have a greater similarity in their physical, chemical, and phenological characteristics, favoring more similar arthropod communities associated with the canopy (Bangert and Whitham 2007).

Oaks are ideal species to study the effect of the genetic diversity of host plants on associated communities (TovarSánchez et al. 2013; Tovar-Sánchez et al. 2015 a, b). This is because many oak species can be considered foundation species due to their wide geographic distribution (Valencia 2004) and dominance in the canopy of forests (TovarSánchez et al. 2013) and because they are habitat to different species. They also show a high frequency of natural hybridization (Curtu et al. 2007; Peñaloza-Ramírez et al. 2010; Valencia-Cuevas et al. 2015), a condition that can promote an increase in genetic diversity (Tovar-Sánchez et al. 2008; Valencia-Cuevas et al. 2014) and the appearance of new features in host plants (Tovar-Sánchez and Oyama 2004) which can be exploited by arthropod communities. However, to date, there are few studies that have evaluated the structure of arthropod communities associated with the canopy of oaks from a genetic perspective. 
Most studies that have evaluated the effect of the genetics of the host plant were conducted in hybrid systems (Preszler and Boecklen 1994; Yarnes et al. 2008). These studies have emphasized the response of arthropods, particularly phytophagous, to the variation found in these zones due to the generation of unique combinations of genetically based features of host plants, which could be associated with the oviposition preferences of insects and with the resistance responses of the plants (Boecklen and Spellenberg 1990, Aguilar and Boecklen 1992). However, most of these studies do not include an analysis to quantify the genetic diversity of the host plant and are based only on theoretical predictions that assume that the presence of two species, rather than one, increases genetic diversity of the host and that genetic diversity increases in hybrid individuals, especially when they are fertile, due to the huge number of genetic combinations that may occur (Whitham et al. 1999).

In general, there are few studies that have assessed a parameter of genetic diversity with respect to a parameter of the oak canopy arthropod community structure. Furthermore, these studies have yielded conflicting results. On one hand, we can mention the case of the complex of Mexican oaks formed by Quercus crassipes and Q. crassifolia; it was found that the composition, abundance, and diversity of the community of endophagous insects (gall-forming wasps and leaf miner moths) were affected by the genetic status of the host tree. Moreover, a significant positive relationship was found between the diversity of gall-forming insects and the genetic diversity of the host plant at the population level (Tovar-Sánchez and Oyama 2006b). Similarly, TovarSánchez et al. (2013) found that the diversity and density of canopy arthropods associated to Q. castanea and $Q$. crassipes responded positively and significantly to the genetic diversity of the host tree at the individual level in central Mexico.

In contrast, Tack et al. (2010) found that genetic diversity had little influence on the community structure of endophagous insects (gall-forming, leaf miner and leaf roller insects) associated with the canopy of Q. robur in Finland. Similar results were reported by Castagneyrol et al. (2012), who found that the genetic attributes of the host plant (genetic diversity, kinship, and genetic identity) had no significant effect on the community of phytophagous insects (endophagous and ectophagous) associated with the canopy of $Q$. robur in France. The absence of a response by the canopy communities associated with Q. robur in Europe is probably due to the lower levels of genetic diversity of European species (whose populations were affected by glaciations) compared to the diversity reported for Mexican oak species (i.e., Magri et al. 2007; Marsico et al. 2009). Vakkari et al. (2006) reported very low levels of genetic diversity $(\mathrm{He}=0.162)$ of $\mathrm{Q}$. robur in Finland. The authors suggest that these low values of genetic diversity may be explained by several factors: the high degree of fragmentation of the populations that this country represents the limits of the distribution of $Q$. robur and that $Q$. petraea, a species with which frequently exchange genetic material in central Europe, is not distributed in this country. Under this scenario, other factors may exert a greater influence on the structure of the associated communities. Bangert et al. $(2006,2008)$ proposed that if genetic variability does not increase on par with environmental variability, the latter will start to become a more important factor for the organization of the communities.

Because there are few studies that have evaluated the ecological consequences of the genetic diversity of oaks on their canopy arthropod communities and also because the results have been contradictory, it is essential to conduct further research to determine whether the effect of the genetic diversity of the host oak is the rule or the exception. Undoubtedly, the study of the genetic diversity of oaks and of its effect on the arthropod fauna associated with the canopy is a line of research with potentially important implications for conservation; previous studies in different species of poplar, eucalyptus, and willows (with attributes of foundation species, like oaks) suggest not only that genetic diversity influences the fitness of unique species but also that its benefits can extend to the associated arthropod communities.

\section{Host plant hybridization}

Interspecific hybridization is a common phenomenon in plants (Whittemore and Schaal 1991; Avise 1994; Rieseberg 1995; López-Caamal and Tovar-Sánchez 2014), especially common among species of the genus Quercus (Curtu et al. 2007; Peñaloza-Ramírez et al. 2010; Valencia-Cuevas et al. 2015). Particularly, for 20 years, the hybrid zones have been attractive as unique scenarios to study the effects of natural hybridization on plant-insect interactions (Fritz et al. 1994, 1998; Whitham et al. 1999; Wimp et al. 2004; Yarnes et al. 2008). Different studies have documented that the interspecific hybridization of plants can influence the distribution of herbivores between hybrids and putative parentals in the process of evolution of herbivores and in the coevolution process of insects and plants (Fritz et al. 1994; Fritz 1999; Dungey et al. 2000; Hochwender and Fritz 2004; Bangert et al. 2005). Community-level studies have found that arthropods show five patterns of response to the hybridization of their host plants: (1) Susceptibility: more species of insects in hybrid hosts than in parental species (Fritz et al. 1994; Whitham et al. 1994; Fritz 1999), (2) Dominance: hybrids support as many species of herbivores as one of the parental species (Fritz et al. 1994, 1996; Fritz 1999), (3) Resistance: hybrids support less herbivores than 
both parental species (Boecklen and Spellenberg 1990; Fritz et al. 1994, 1996; Fritz 1999), (4) Additivity: hybrids support an intermediate number of insects compared to the parental species (Boecklen and Spellenberg 1990; Fritz et al. 1994, 1996; Fritz 1999) and, finally, (5) No differences: hybrids have an equal number of herbivorous insects than both parental species (Fritz 1999). The existence of these different patterns of response of arthropods in hybrid zones has been attributed to the age and extent of the geographical distribution of the hybrid zone, to environmental gradients, to the genetic status of hybrids, to the backcross direction, to the morphological and chemical similarity of the parental species, and to the genetic mechanisms that determine the inheritance of resistance mechanisms in hybrids (Boecklen and Spellenberg 1990; Fritz et al. 1994; Strauss 1994).

In the particular case of oak canopy arthropods, the previously described responses to the hybridization of the host plants have all been recorded. For example, the hypothesis of susceptibility has been reported in the case of the hybrids of the $Q$. crassipes $\times Q$. crassifolia complex in Mexico, which supported the greatest richness and the highest number of rare species of ectophagous insects compared to parental individuals (Tovar-Sánchez and Oyama 2006a). Also, there are studies that have supported the hypothesis of dominance. For example, the $Q$. dumosa $\times Q$. engelmannii complex in which hybrids showed a similar density of Nepticula spp., Tischeria spp., and Coptodisca spp. compared to pure individuals of Q. gambelli (Yarnes et al. 2008). Other studies have supported the hypothesis of resistance reporting a lower density and diversity of leaf mining insects (Lepidoptera: Nepticulidae and Gracillariidae) and gall-forming wasps (Hymenoptera: Cynipidae) in hybrid plants of the Quercus depressipes $\times Q$. rugosa and Q. emoryi $\times Q$. coccolobifolia complexes in northern Mexico (Boecklen and Spellenberg 1990), and a lower density of leaf miner moths (Phyllonorycter) in hybrid plants of the Q. grisea $\times$ Q. gambelii complex in New Mexico (Preszler and Boecklen 1994). The additive hypothesis has been supported by Aguilar and Boecklen (1992), who analyzed the density patterns of herbivores (leaf miner moths: Lepidoptera: Nepticulidae and Gracillariidae; gall-forming wasps: Hymenoptera: Cynipidae) in the Q. grisea $\times Q$. gambelii complex in New Mexico and found that the hybrid hosts maintained intermediate densities compared to the parental hosts. Similar responses have been reported by Ishida et al. (2003), Tovar-Sánchez and Oyama (2006a, b) and Yarnes et al. (2008) in the Q. crispula $\times$ $Q$. dentata complex in Japan, $Q$. crassipes $\times$ Q. cassifolia in Mexico and Q. griseae $\times$ Q. gambelii in New Mexico, respectively. Finally, the hypothesis of no differences was demonstrated by the abundance of phytophagous insects in the hybrids of the Q. crispula $\times Q$. dentata complex in Japan (Ishida et al. 2003).

It has also been detected that the response of arthropods can be different in the same system. In the $Q$. crispula $\times$ Q. dentata complex in Japan, it was found that the abundance of phytophagous insects (leaf miner and leaf-chewing insects) responded differently to the hybridization of the host plant; the hybrids showed intermediate abundance (additivity), similar to one of the parental species (dominance) or similar to both parental species (no differences) (Ishida et al. 2003). The authors suggest that this differential response of herbivores resulted from differences in the expression of foliar chemistry in different genotypes of the host plant (F1, backcrosses) generated as a result of different patterns of introgression (unidirectional or bidirectional) in this system.

\section{Hybrid bridges and change of host species}

The mechanisms by which arthropod species can switch to a new host plant species are crucial to understanding the coevolution of plant-insect interactions (Floate and Whitham 1993). Currently, the change of host plant species has been explained by the hypothesis of the preadaptation or mutation required by arthropod species to "jump" and switch from one host to another (Floate and Whitham 1993). The pre-adaptation hypothesis suggests that herbivores are pre-adapted to switch to a new host species, but they do not do it because the new host is not present (Thomas et al. 1987). In contrast, when herbivores are not pre-adapted to the host, one or more key mutations must occur for the herbivore to be able to recognize a new and better host (Jermy 1984). Floate and Whitham (1993) proposed the hybrid bridge hypothesis, which predicts that hybrid plants facilitate the change of arthropods from one host species to another. For example, Keim et al. (1989) found that when a plant species presents allopatric distribution (with respect to a second potential host), this scenario acts as a barrier to the switching of hosts by the herbivore. The preadaptation hypothesis suggests that arthropods will not switch host species unless the hosts have a sympatric distribution (Thomas et al. 1987). But if two species hybridize so that the space between their distributions constitute "space bridges" formed by hybrid intermediaries, arthropods may switch to the new host species through the hybrids even though the parental plant species maintain an allopatric distribution.

This change of host can be affected by the hybridization patterns of plants, which determine the hybrid genotype that opens the genetic space between the parental species. Floate and Whitham (1993) proposed four hypothetical scenarios: first, no hybridization between the parental species; second, if parental species hybridize and produce 
sterile F1 offspring, all hybrid individuals will have $50 \%$ of the genome of each parental species; third, if the parental species show hybridization and produce sterile F1 offspring, the hybrids will show unidirectional introgression, i.e., the hybrids will cross with only one of the parental species to produce a genotype continuum of hybrids towards that parent. Under this scenario, the change of one host species for another is facilitated, but the space that remains still represents a barrier to the gradual change of host. The fourth scenario proposes that hybridization between parental species will produce fertile F1 hybrid individuals, which will backcross with the two parental species, generating a pattern of bidirectional introgression that will result in a genetic continuum between the hybrid individuals and the parental species, facilitating the change of host (Floate and Whitham 1993).

Considering the high frequency of hybridization between species of oaks (Spellenberg 1995; Howard et al. 1997; Tovar-Sánchez and Oyama 2004; Curtu et al. 2007; Peñaloza-Ramírez et al. 2010; Valencia-Cuevas et al. 2015) and that hybrid host plants facilitate the establishment of herbivore species (Whitham 1989; Boecklen and Spellenberg 1990; Floate and Whitham 1993; Tovar-Sánchez and Oyama 2006a), one would expect that the change of host by herbivores between species of the genus Quercus would be well documented. However, actually, this subject has been little studied. In a recent study, Tovar-Sánchez and Oyama (2006b) found that Q. × dysophylla (hybrid resulting from a cross between $Q$. crassipes and $Q$. crassifolia) has $25.7 \%(n=9)$ of the insects that are specific to the two parental species supporting the hypothesis of the hybrid bridge. A proposal associated with this hypothesis is that the hybridization patterns of plants (described above) can influence the structure of their communities. For example, it has been reported that species richness can be higher in hybrid zones with bidirectional introgression, where a genetic continuum can facilitate the accumulation in hybrids of herbivores of the two parental species (Whitham et al. 1999); intermediate species richness has been found in hybrid zones formed by unidirectional introgression where hybrids can accumulate herbivore species associated with only one of the parental species; the lowest species richness was found in hybrid zones formed by sterile F1 hybrids due to the lack of backcrossing with the parental species, which prevented the formation of a continuum of hybrid genotypes that could act as bridges for host switching (Whitham et al. 1999). In this regard, the study by Tovar-Sánchez and Oyama (2006b) in seven hybrid zones of the Q. crassipes $\times Q$. crassifolia complex in Mexico showed that in the hybrid zone where bidirectional introgression was detected, the hybrids supported the highest richness of insects compared to hybrids in the other six hybrid zones where there was unidirectional introgression (asymmetric).

Considering the high frequency of hybridization between species of the genus Quercus, the studies that have evaluated the effect of hybridization suggest that hybrid zones are centers of biodiversity of endophagous and ectophagous insects (Tovar-Sánchez and Oyama 2006a, b) and areas of great potential for exploring ecological and evolutionary processes at multiple levels (Strauss 1994). Therefore, the conservation of these zones may be crucial for the maintenance of arthropod communities associated with the canopy of the oak species involved in hybridization events.

\section{Origin of the species (native or introduced)}

The geographical distribution of plants can vary naturally due to geological or climatic changes or to anthropogenic causes (Strong et al. 1984), a situation that has allowed to compare the structure of arthropod communities in native and exotic habitats. For example, community-level studies have revealed that introduced plants support a lower total diversity of phytophagous arthropods and a change of herbivores from specialists to generalists compared to native plants (Colautti et al. 2004; Cripps et al. 2006; Hill and Kotanen 2010). This has been explained on the assumption that native herbivores do not find introduced plants to be suitable hosts because they prefer to feed on plants with which they share a common evolutionary history (Bernays and Graham 1988). Furthermore, the differences in the structure of guilds (generalists vs. specialists) between native and introduced plants are explained because specialists are more closely linked to the host plant; thus, they are expected to need more adaptations in order to be able to use a new host species (Gaston et al. 1992). Alternatively, other studies have shown that the abundance, richness, and foliar damage caused by arthropods is not different between native and introduced plants (Agrawal and Kotanen 2003; Frenzel and Brandl 2003; Agrawal et al. 2005), suggesting that some specialist herbivorous insects and native generalists can use the resources provided by introduced plants (Keane and Crawley 2002; Parker et al. 2006), especially when exotic plants coexist with closely related native plants, with whom they share similar mechanisms of defense (Tallamy 2004). In this case, natural enemies may not be associated in this new relationship, which may facilitate their establishment and an increase in herbivory levels. It has even been found that the abundance of herbivores may be greater in introduced plants than in native plants (Cripps et al. 2006), suggesting that native plants may be better adapted to the local herbivore fauna (Shea and Chesson 2002) or that introduced plants represent predator-free spaces, facilitating the 
switch to a new host species (Keane and Crawley 2002; Murphy 2004).

There are few studies on the arthropod fauna associated with the canopy of oaks. However, the studies found reported a decrease in the abundance of arthropods in introduced host plants. For example, Southwood et al. (1982) found that the richness, diversity, and abundance of phytophagous insects associated with the canopy of $Q$. robur was lower in South Africa, where it is an introduced species, compared to Britain, where it is a native species. Similarly, Auerbach and Simberloff (1988) found a lower density of leaf miner specialists in Q. acutissima in Florida, where this species is an introduced one. More recently, Southwood et al. (2004) studied the fauna of phytophagous insects of two species of native oaks (Q. robur and Q. petraea) and two species introduced to Britain (Q. cerris and Q. ilex); they found that the two introduced species supported a lower density and richness of gall-forming insects and leaf miners compared to native species. With this same system, Southwood et al. (2005) found that, as in the case of the guild of herbivores, there was lower species richness and abundance of predators and parasitoids in introduced host species compared to native ones.

In general, there are very few studies that have evaluated the effect of the origin of the host oak species on the arthropod fauna associated with the canopy. However, assessing the evolution process of organisms that lack a history of coexistence or the response to the origin of the host species among arthropod specialists and generalists can provide very important information in terms of the conservation of native diversity and for designing management strategies for biological control.

\section{Chemistry of the host plant}

The chemical compounds of plants that can influence arthropod communities can be grouped into two categories: food and defense (Strong et al. 1984). In the first case, leaf nitrogen is a critical component for phytophagous insects (Strong et al. 1984), as there are records of a positive relationship between leaf nitrogen concentration and the rate of growth, reproduction, and survival of herbivorous insects (Mattson Jr. 1980). In addition, leaf nitrogen content can vary between species of plants and through foliar ontogeny (Jeffries et al. 2006; Ricklefs 2008), influencing the selection of the host plant by herbivores (Coley and Barone 1996). For example, a low nitrogen content has been associated with a reduced preference and performance of insects, as the palatability of the plant for herbivores depends on the ratio of carbon/nitrogen in the leaves (Schädler et al. 2003).
In the case of arthropod associated to oak species, several studies have supported the hypothesis proposed by Mattson Jr. (1980); these studies found a positive relationship between leaf nitrogen concentration in Q. alba (Wold and Marquis 1997), Q. prinus, Q. rubra (Forkner and Hunter 2000), Q. dentata (Nakamura et al. 2008), Q. geminata, Q. laevis (Cornelissen and Stiling 2006, 2008), Q. alba, Q. coccinea, and Q. velutina (Marquis and Lill 2010) and the density of herbivorous insects (i.e., leaf miners, leaf-chewing, gall-forming, and leaf rollers). Similarly, it has been reported that higher leaf nitrogen content in Q. crispula favors greater species richness of leaf-chewing insects (Lepidoptera) (Murakami et al. 2005, 2007, 2008).

In general, there are records of a significant effect of the individual plant species on the concentration of nitrogen and secondary metabolites (Laitinen et al. 2000; Osier et al. 2000; Cornelissen and Stiling 2008; Marquis and Lill 2010), suggesting that such variability affects the foraging activity and spatial distribution of arthropods. It has been suggested that the variation in the concentration of nitrogen and secondary metabolites depends on the following: (1) the genotype of the host plant (Glynn et al. 2004), (2) environmental conditions (Larsson et al. 1986; Henriksson et al. 2003; Niinemets and Kull 2003), and (3) the resources of the host plant (Ricklefs 2008). In addition, the chemical composition of the leaves of host plants may change as a result of damage by herbivores (plant's induced response), which has an effect on subsequent attacks (Karban and Myers 1989). This induced response has also been documented in oaks. For example, Wold and Marquis (1997) found a decreased nitrogen content in seedlings of $Q$. alba that had previously been subjected to herbivory in an experimental field in Missouri. This change in foliar chemical composition favored a reduction in the subsequent damage caused by herbivore insect compared to the seedlings that had initially shown lower herbivory.

Furthermore, tannins have been the most studied chemical components of oaks regarding their effect on the structure of arthropod communities (Feeny 1970; Abrahamson et al. 2003; Forkner et al. 2004; Murakami et al. 2005, 2007, 2008; Yarnes et al. 2008). In a pioneering work, Feeny (1970) documented a significant and negative relationship between the concentration of leaf tannins in Q. robur and the abundance of phytophagous insects (Operophtera brumata), suggesting a defensive role for these compounds. Specifically, tannins have been reported to reduce the growth and survival of phytophagous insects (Kause et al. 1999; Kopper et al. 2002), to produce lethal deformities (Barbenhenn and Martin 1994) and to increase rates of parasitism (Faeth and Bultman 1986). It has also been documented that there is a negative relationship 
between the concentration of tannins and the biomass of Lepidoptera in the pupal stage (Lill and Marquis 2001).

Other studies in oaks found the same results as Feeny (1970); they reported a negative relationship between the concentration of tannins in the plant and the abundance and richness of herbivores (leaf-chewing insects, leaf miners, and gall-forming) that inhabit the canopy of $Q$. alba, Q. velutina (Le Corff and Marquis 1999; Forkner et al. 2004), Q. crispula (Murakami et al. 2005, 2007, 2008), Q. geminata, Q. laevis (Cornelissen and Stiling 2006, 2008), and Q. gambelii $\times$ Q. grisea (Yarnes et al. 2008).

It has also been well documented that plants produce other chemical substances (i.e., oxalic acid, alkaloids, phenolic content, toxic lipids, flavonoids, and lignins) that act as defenses or insect attractants (Becerra et al. 2001; Salminen et al. 2004). In response to these signals or chemical defenses, arthropod communities can have different structures (Inoue 2003). In particular, it has been documented that gall-forming insects (Cynipidae) are a group that responds sensitively to differences in foliar chemistry between oak host species. For example, Abrahamson et al. $(1998,2003)$ found that the community composition of gall-forming wasps in six species of oak (Q. laevis, Q. myrtifolia, Q. inopina, $Q$. chapmanii, Q. geminata, and Q. minima) in the east of the USA was different and unique for each species. Similar results were reported for the $Q$. crassipes $\times Q$. crassifolia complex in Mexico (Tovar-Sánchez and Oyama 2006b), for Q. infectoria and Q. brantii (Nazemi et al. 2008) in Iran and for Q. castanea and Q. crassipes (Tovar-Sánchez et al. 2013) in Mexico. The authors suggest that this close relationship is a result of the high degree of specialization of insects to host plant chemicals.

Moreover, oaks have been found to show seasonal variations in foliar chemistry. Some examples have been documented in Q. robur (Feeny 1970; Salminen et al. 2004), Q. alba, Q. velutina (Le Corff and Marquis 1999), Q. alba (Lill and Marquis 2001), Q. crispula (Murakami et al. 2005, 2007, 2008), Q. geminata, and Q. laevis (Cornelissen and Stiling 2006, 2008). These studies found a temporal variation in the nutritional quality of the leaves, as the ontogenetic development of leaves progressed, the content of tannins and lignins increased and the content of water and nitrogen decreased (Feeny 1970; Lill and Marquis 2001; Forkner et al. 2004, Murakami et al. 2005). Several studies have shown that this seasonal variation in foliar chemistry is reflected in the structure of the arthropod community associated with the canopy of oaks in terms of composition, species richness, diversity, biomass, and abundance (Southwood et al. 2004, 2005; Murakami et al. 2005, 2007; Tovar-Sánchez 2009; Tovar-Sánchez et al. 2013). In general, the pattern that has been observed is that the richness, diversity, abundance, and biomass of canopy arthropods decrease as the season progresses, while the composition varies in response to changes in the chemistry of the host plant.

Considering the great diversity of oak species worldwide, and the great diversity of canopy arthropods, the study of the chemistry of the host and of its influence on plant-insect interactions provides an ideal scenario to study the oviposition preferences, food, ontogenetic performance, host switching, and community structure of arthropods in response to variations in the chemical defenses of the host plant.

\section{Spatial variation}

One of the most important patterns of the communities of plants and animals is that organisms are not spread evenly in nature (Agrawal et al. 2006). A consequence of this phenomenon is that the identity and intensity of the interactions between plant and insect species shows a high spatial variability (Agrawal et al. 2006). For example, if the composition and diversity of plant communities vary predictably across habitats and biogeographical zones (Gurevitch et al. 2002), it is reasonable to assume that the strength of plant-herbivore interactions can also vary. For example, a latitudinal gradient in the intensity of herbivory is predicted at the global scale, which has led to a greater diversity of unpalatable plants in the tropics compared to temperate regions (Pennings and Silliman 2005). In addition, plant communities show large spatial differences in richness, genetic diversity, abundance, and total biomass, helping create heterogeneous habitats that promote differences in arthropod communities. In forests, horizontal (between localities, Gering and Crist 2000; Summerville et al. 2003a, b) and vertical spatial variation (between layers) can have an influence on canopy insect communities (Le Corff and Marquis 1999; Simmon and Linsenmair 2001; Forkner et al. 2004; Barber and Marquis 2009). The horizontal differences can be generated by changes in biotic (i.e., dominant canopy species, composition, abundance, and diversity of host species, forest age) and abiotic factors (i.e., geological age, topography, soil type, altitude) between localities (Gering et al. 2003; Price et al. 2004). On the other hand, vertical variation results from the presence of different layers of vegetation in the forest, which gradually modulates biotic (i.e., floristic composition, leaf area, biomass density, species diversity) and abiotic parameters (i.e., temperature, wind velocity, sunshine, humidity) along a vertical gradient running from the forest floor to the canopy (Basset et al. 2003a). This stratification of vegetation results in a great diversity of microhabitats, which can support different communities of arthropods (Parker 1995; Forkner et al. 2004; Barber and Marquis 2009). However, there has been no consensus among researchers to define the canopy vertically in 
temperate forests, as there are some who recognize two layers, overstory (canopy and aerial part), and understory (shrubs and herbaceous plants, Le Corff and Marquis 1999; Lewinsohn et al. 2005; Murakami et al. 2005) and some who divide the canopy into an upper and a lower layer (Wagner et al. 1995; Simmon and Linsenmair 2001). In general, the spatial variation of resources and conditions between locations and layers generates changes in the composition, richness, abundance, and diversity of arthropod communities associated with canopies (Strong et al. 1984; Gering et al. 2003). On the other hand, the studies that have been conducted on the vertical structure of arthropod communities have not found consistent patterns of stratification. In some cases, species are more abundant in the lower canopy (Basset 1991); in other cases, they are more abundant in the upper canopy (Meagher and Hull 1987), while in other cases, the species are evenly distributed (Brown et al. 1997).

In the particular case of the arthropod fauna associated with the canopy of oaks, it has been found that parameters such as composition, richness, and diversity respond to the spatial variation between localities and layers. In the first case, Gering et al. (2003) found that the communities of coleoptera associated with the canopy of Q. alba and Q. rubra were different in terms of composition, richness, and diversity between sites and ecoregions, which they attributed to the heterogeneity of resources and conditions in the different scales studied. Similarly, Tovar-Sánchez et al. (2003) found that the composition, richness, and diversity of the arthropod community associated with the canopy of $Q$. castanea, Q. crassipes, Q. crassifolia, Q. greggii, Q. laeta, and Q. rugosa in three locations in central Mexico showed significant differences in response to different degrees of disturbance and fragmentation between locations. Similarly, Price et al. (2004) and Barber and Marquis (2009) reported differences between locations in the species richness of gall-forming insects (Cynipidae) associated with the canopy of Q. myrtifolia and in the abundance of herbivorous and predatory canopy arthropods associated to Q. alba.

In particular, the spatial variation in the physical and chemical characteristics of the leaves within the canopy of oaks was documented (Roslin et al. 2006), and its effect on the arthropod communities associated was evaluated. However, the studies that have examined the stratification of arthropod communities in the canopy of oaks have shown contrasting results. On one hand, some studies have reported that the upper canopy supports the highest density and abundance of arthropods; such is the case of the study by Simmon and Linsenmair (2001), who found that the density of herbivorous insects associated with the canopy of $Q$. subsericea in a rainforest in
Borneo, Malaysia, was greater in the upper canopy compared to the lower canopy, suggesting that in these microenvironments, differences in temperature or in foliar chemistry, and palatability of leaves between layers could be responsible for differences in the density and abundance of the associated arthropod species. In addition, this study found differences in the composition and abundance of the arthropod community between layers; in the lower layer, homoptera and ants were the dominant groups, while at in the upper layer, the dominant groups were diptera and hymenoptera (except ants). On the other hand, there are studies that have found that the richness and abundance of oak canopy arthropods are lower in the canopy than in the understory. For example, Le Corff and Marquis (1999) found that the richness of herbivorous insect species (larvae of Lepidoptera) in $Q$. $a l b a$ and $Q$. velutina was higher in the understory than in the canopy, suggesting that environmental factors such as the amount of light can be important in explaining the results. In addition, Nakamura et al. (2008) found that $Q$. crispula showed a greater abundance of herbivorous leaf miners in the canopy compared to the understory, suggesting that the results were determined by the higher leaf nutritional quality in the understory compared to the canopy.

A higher species richness was also been found in the inside of the canopy of oaks. For example, Sobek et al. (2008) found that the species richness of mites (Acari: Oribatida) associated with the canopy of Q. robur was higher in the inside of the canopy, suggesting that mites are able to live in the thick branches near the trunk, while they become rare in the outer branches, which are constantly exposed to rain, wind, and solar radiation, making these sites unfavorable habitats for many arthropods.

In addition, there are studies that have found that vertical stratification in arthropod communities associated with the canopy of oaks changes seasonally in response to changes in the nutritional quality of the leaves between layers. Examples of this are the patterns of vertical stratification in the community of leaf-chewing insects associated with the canopy and understory of $Q$. alba and Q. velutina (Forkner et al. 2004) and in the community of lepidopteran larvae in the canopy and understory of Q. crispula (Murakami et al. 2005).

The influence of the spatial variation of the host plant on the arthropod fauna associated with oak species is probably due to the lack of consensus about the vertical structure of the canopy in temperate forests, which leads to comparing arthropod groups with different habitat preferences belonging to different guilds and in unequal stages of development. A control of the above variables could identify clear response patterns of canopy arthropods to the vertical spatial variation in oak forests. 


\section{Seasonal variation}

Temperate deciduous forests show predictable changes in highly synchronized phenological events, as most species of trees show sprouts of leaves in spring, followed by senescence and eventual leaf fall in autumn (Strong et al. 1984; Murakami et al. 2007). Consequently, these seasonal cyclical changes change the structure of the arthropod community associated with the canopy. The change in the composition, as well as the decrease in relative abundance and richness of canopy arthropod species in temperate forests as seasonality advances is well documented (Gering et al. 2003; Southwood et al. 2004, 2005; Murakami et al. 2005, 2007). In this regard, it has been suggested that in temperate forests, the nutritional quality of the leaves decreases as the season progresses (Feeny 1970); the leaves become harder, its water and nitrogen content decreases, and the content of tannins and fibers increases (Feeny 1970 Le Corff and Marquis 1999; Lill and Marquis 2001; Salminen et al. 2004; Cornelissen and Stiling 2008; Murakami et al. 2007, 2008). These foliar changes have also been used to explain the differences in the composition of arthropod communities; as the season progresses, species with different feeding preferences appear (i.e., leaf-chewing insects at the start of the season and sap-sucking insects at the end, Strong et al. 1984; Southwood et al. 2004; Stork and Hammond 2013).

In addition, temperate forests exhibit a seasonal rainfall pattern in which the rains are distributed throughout a season that lasts $6-7$ months and is interrupted by a dry season that can last from 5-6 months (Rzedowski 1978). This seasonal variation has several effects on the phenology of the plants and on their associated arthropod communities; in the rainy season, there is an increase in the formation of branches, leaves and fruits, as well as in the development of epiphytic plants, and this favors the production of a range of resources and conditions that can be used by canopy arthropods. This can promote changes on a microclimate level (Basset and Novotny 1999; Peeters et al. 2001), as well as an increase in environmental heterogeneity, which can be used by arthropods (Yarnes and Boecklen 2005). In addition, during the rainy season, the young leaves are the most abundant and nutritious, they are less hard and have less chemical defenses (Kursar and Coley 2003; Boege 2004; Coley et al. 2006). Finally, the increase of vegetation in the forests (i.e., annual vegetation) during the rainy season can serve as a bridge so that new species of arthropods have a greater chance of colonizing new trees (Basset et al. 1992; Campos et al. 2006).

Studies in oaks have documented the effect of host plant phenology and seasonality on the canopy arthropod fauna. In the first case, a decrease in the density, richness, diversity, and biomass of insects associated with the canopy of oaks has been detected as the season progresses. Examples include the community of leafchewing insects associated with the canopy of Q. alba and Q. velutina in Missouri (Forkner et al. 2004), the community of phytophagous insects associated with the canopy of $\mathrm{Q}$. cerris, Q. ilex, $\mathrm{Q}$, petraea, and $\mathrm{Q}$. robur in a forest in France (Southwood et al. 2004, 2005), and the community of beetles associated with the canopy of Quercus spp. in two forests in Turkey (Şen and Gök 2009).

Furthermore, it has been found that during the rainy season the canopy of oaks supports greater species diversity, richness, density, and biomass compared to the dry season. Examples of this have been reported in the community of collembola inhabiting Tillandsia spp., an epiphytic plant of the canopy of Quercus spp. in a temperate forest in central Mexico and in the community of ectophagous insects associated with the canopy of $Q$. laurina and Q. rugosa (Tovar-Sánchez 2009) and of $Q$. castanea and Q. crassipes (Tovar-Sánchez et al. 2013) in a temperate forest in Central Mexico.

The high sensitivity of arthropod species to changing environmental parameters can be a tool to predict the effect of climate change on biodiversity in oak forests, using canopy arthropods as bioindicators.

\section{Habitat heterogeneity}

The hypothesis of habitat heterogeneity is one of the cornerstones of ecological studies; it predicts that structurally more complex habitats provide a wider range of resources and conditions, which favors the establishment of a greater diversity of species (Halaj et al. 2000, Tews et al. 2004; Affeld 2008). Because plant communities determine the physical structure of the environment, they have great influence on the structure of animal communities (Strong et al. 1984). For example, Martinsen and Whitham (1994) found that the hybrid plants of the Populus angustifolia $\times$ P. fremontii complex had a more complex architecture compared to the putative parental species. This favored the presence of a greater number of bird nests in hybrid plants and, therefore, an increase in the richness of associated bird species.

In the case of arthropods inhabiting the canopy of trees, the structure and complexity of their habitat is determined by the abundance and architecture of the plants (i.e., shape and size of leaves, buds, twigs, and epiphytes as well as the bark texture, Halaj et al. 2000; Affeld 2008; Ulyshen and Hanula 2009).

In addition, important resources for herbivores such as food, shelter, foraging sites, oviposition, and sexual deployment are directly related to habitat heterogeneity (Halaj et al. 2000). For example, it has been documented 
that the structural complexity of the canopy is increased by the presence of epiphytic plants (i.e., orchids, bromeliads, ferns, mosses, and lichens), since they differ significantly in structure, growth habit, and function, providing a great diversity of microhabitats and resources (Ishii et al. 2004; Affeld 2008) that can be used by arthropods.

Moreover, the forest canopy can be structurally more complex when it is formed by more than one species (Ishii et al. 2004; Novotny et al. 2006; Sobek et al. 2009), resulting in a more complex environment due to the differences in plant architecture and the increased availability of resources and conditions (Novotny et al. 2006). This hypothesis is supported by studies that have shown that some groups of birds (Martinsen and Whitham 1994; Poulsen 2002), mammals (Southwell et al. 1999; Williams et al. 2002), and amphibians (Atauri and Lucio 2001) respond positively to the physiognomic complexity of host plants and, furthermore, by studies that have shown a positive effect of taxonomic diversity of host plant species on the associated communities (Siemann et al. 1998; Beals 2006).

In the case of arthropods, it has also been reported that more complex habitats offer a wider range of niches that can support a larger number of species (Humphrey et al. 1999; Hansen 2000; Hamer et al. 2003, Lassau and Hochuli 2005). Specifically, a positive relationship between species richness of arthropods and plant diversity has been reported (Gaston 1991; Siemann et al. 1998; Novotny et al. 2006; Sobek et al. 2009).

In addition, several authors have suggested that the structural complexity of the forest increases with age, i. e., mature forests are structurally more complex compared to young forests or plantations (Schowalter 1995; Evans and Jukes 2000; Jeffries et al. 2006), as the former have larger trees in terms of height and biomass. Moreover, mature forests contain trees of different ages, which favor greater structural complexity (Ishii et al. 2004).

Several studies in oaks have documented that structurally more complex habitats offer more resources and conditions to canopy arthropods, which has a positive effect on the richness, diversity, and abundance of their communities. For example, Marquis et al. (2002) demonstrated the effect of the architecture of $Q$. alba on the abundance of shelter-building caterpillars. Their results showed a positive relationship between the structural complexity of the canopy of the mentioned species (percentage of overlapping leaves) and abundance of caterpillars (Lepidoptera), suggesting the importance of plant architecture for these herbivores. Subsequently, Lill and Marquis (2003) found, in the same system, that the building of shelters by these caterpillars favors a greater structural complexity in Q. alba, resulting in an increase in the species richness of leaf-chewing insects.

Other studies have shown the positive effect of structural habitat complexity related to forest age on the richness of the arthropod fauna associated with the canopy. An example of this is the community of leaf-chewing insects associated with the canopy of $Q$. alba and $Q$. velutina (Marquis and Le Corff 1997; Marquis et al. 2000) and the lepidopteran community associated with the canopy of Quercus spp. (Summerville and Crist 2002, 2003).

Recognizing the positive effect of habitat heterogeneity on the arthropod communities associated with the canopy could be useful to propose management strategies that promote the structural complexity of the canopy of oak forests and thereby benefit the associated arthropod communities.

\section{Biotic interactions}

A community is a group of species that share the same habitat, in which, at least some of the component species populations will interact with each other. These interactions and the resulting population dynamics underlie broad patterns in the structure of ecological communities (Strong et al. 1984). For example, in arthropod communities the interactions can broadly affect the local abundance and distribution of specialist and generalist predators and parasitoids, as well as herbivores in several feeding guilds (Styrsky and Eubanks 2007; Tack et al. 2012). In general, the interactions between different species inside the communities can be established "horizontally," when the species are potential or actual competitors or "vertically," when the interactions involving natural enemies (Morin 1999).

In particular, interspecific competition is any mutually negative interaction between two or more species within the same guild or trophic level (Polis and Holt 1992). Competitive interactions manifest themselves as reduced abundance, decreased fitness, or a decrease in some fitness component, such as body size, growth rate, fecundity, or survivorship (Begon et al. 2005). The assumption is that decreases in fitness components would eventually cause the reduction in the abundance of species involved, a condition that could change the community structure (Hooper et al. 2000). Competition between species for limited resources has been regarded as a process that structure ecological communities, because it limits the number of coexisting species, molding and constraining what those species do, where and how they feed, their body sizes, seasonal distribution, etc. (Strong et al. 1984; Begon et al. 2005).

For insects, the role of intra- and interspecific competition in ecological theory has changed throughout the years from the notion that competition was weak and 
infrequent on phytophagous insect communities in the early 1980s (Lawton 1982; Strong et al. 1984), to the resurrection of the importance of competition among phytophagous insects in the 1990s (Denno et al. 1995; Reitz and Trumble 2002). Most notably, Kaplan and Denno (2007) reviewed the evidence for competition in phytophagous insects from 145 published studies and found signal for interspecific competition in $73 \%$ of the individual cases compared, although the magnitude of effects varied among the variables analyzed.

On the other hand, the ecology theory considers that phytophagous insects are kept rare, relative to the availability of potentially limiting resources, by the impact of natural enemies as insect parasitoids, insect predators, birds, pathogens, etc. (Strong et al. 1984). Hence, it has been suggested that the major processes acting in many phytophagous insect communities work vertically through the food chain, not horizontally with others species in the same trophic level (Morin 1999).

Predation is defined as the interaction between an individual predator and a prey, where the predator benefits from the interaction, while the consumed prey does not (Rosenheim et al. 1993). Predator-prey interactions involve species that reside on many different trophic levels, including the impacts of herbivores on plants, carnivores on herbivores, carnivores on other carnivores, and parasites and parasitoids on hosts. Predators affect community composition in diverse ways. Some predators feed selectively on competitively superior species that would otherwise exclude weaker competitors. This fact enhances the number of prey species that are able to coexist, since predators reduce the interspecific competition among surviving prey species (Murakami and Nakano 2000). For the above mentioned, several studies have proposed predation as a potent agent of natural selection, population regulation, and community structure (Marquis and Whelan 1994; Murakami and Nakano 2000), being considered as one of the most important balancer mechanism of the natural ecosystems.

In contrast, minor importance has been given to positive interactions among species (Morin 1999). The tendency to overlook a positive effect of one species on another neglects the potential importance of some of the more fascinating interspecific interactions that can occur in communities (Morin 1999). This oversight is unfortunate given that mutualisms, while often inconspicuous, are common and potentially important forces that influence the structure and function of communities (Bronstein 1994; Connor 1995; Kiers et al. 2010). Mutualism, defined as a reciprocally beneficial interaction between individuals of two species, is increasingly recognized as a common and important ecological interaction (Bronstein 1994; Stachowicz 2001). Janzen (1985) identified four key types of mutualisms: dispersal, pollination, nutritional, and protective. For example, community-level effects of nutritional mutualisms, such as mycorrhizal association formed between fungi and the roots of many higher plants can influence seedling establishment and the outcome of competition. Likewise, many higher plants are involved in a facultative mutualism with arthropods and vertebrates that pollinate their flowers and disperse their seeds (Bertness and Callaway 1994). While these positive interactions are often emphasized by ecologists who study various forms of plant-animal interactions, their impact on community organization remains little explored (Bertness and Callaway 1994; Morin 1999; Styrsky and Eubanks 2007).

Another example of positive interactions among species is the existence of ecosystem engineers. Despite controversies about the appropriate use of the term "ecosystem engineering" (Jones and Gutiérrez 2007), it is currently a well-recognized type of positive ecological interaction (Hastings et al. 2007; Burchsted et al. 2010). Ecosystem engineers are organisms that directly or indirectly control the availability of resources for other organisms by causing physical state changes in biotic or abiotic materials (Jones et al. 1997) influencing local patterns of biological diversity. In this sense, Romero et al. (2014) conducted a meta-analysis of 122 studies which explored effects of animal ecosystem engineers on species richness of other organisms in the community. The analysis revealed that the overall effect of ecosystem engineers on diversity is positive and corresponds to a $25 \%$ increase in species richness, indicating that ecosystem engineering is a facilitative process globally.

Specifically, this review revealed that the interaction among species is a factor that has impact on the abundance, distribution, and diversity of arthropods associated to oak canopies. In particular, we found that parameters such as composition, abundance, and species richness respond to the interactions between species as depredation, competition, and mutualism. For example, it has been reported that arthropod communities associated to oak canopies respond to predation by natural enemies as birds (Gunnarsson and Hake 1999; Murakami and Nakano 2000; Barber and Marquis 2009; Böhm et al. 2011; Schönrogge et al. 2013; Ceia and Ramos 2014), bats (Böhm et al. 2011), parasites, and parasitoids (Sanchez et al. 2013), in terms of abundance. However, most the studies have evaluated the influence of birds as regulators of species populations that integrate the arthropod communities. In this context, the study of Murakami and Nakano (2000) found that predation by two bird species (Parus major and Sitta europaea) reduced the population sizes of herbivorous insects associated to Q. crispula in Japan. These results highlight the function of birds as abundance regulators of the herbivores insects in canopy forest 
communities and its role in the community structure. Similarly, Ceia and Ramos (2014) revealed the importance of several bird species as potential regulators of the abundance and distribution of defoliator insects associated to Q. robur and Q. rotundifolia canopy in the Mediterranean. In contrast, Lichtenberg and Lichtenberg (2002) studying the interactions among insectivorous birds, arthropods, and white oak saplings (Quercus alba) in a temperate deciduous forest did not find a detectable influence of birds on leaf-chewer densities in either year.

On the other hand, Nakamura et al. (2008) analyzed the population dynamics of several leaf miners on a deciduous oak $Q$. dentata for 9 years in northern Japan. The authors found that density-dependent effects were not explicit in the population dynamics of the species studied. The authors suggested that interspecific competition is not a factor that modeled the community structure in this system, because leaf miners species are often associated with diverse parasitoid species and they are sometimes subjected to the top-down population regulation by these enemies. In order to understand whether parasitoids mediate interactions of the two host leaf miner species (Phyllonorycter permilis and P. leucocorona), Nakamura and Kimura (2009) studied the parasitism rate in this system. The authors reported a high parasitism rate (24.1-92.6 \% in P. persimilis and 58.981.7 \% in P. leucocorona) suggesting that parasitism was a major mortality factor in these Phyllonorycter species and a promotor of both species coexistence. Though the parasitoid composition was different between the two hosts species, most parasitoids were able to parasitize both leaf miner species, a condition that suggests that the present parasitoids could mediate interactions between the present leaf miner species.

In addition, the influence of positive interactions on arthropod community structure associated to oak canopy, as mutualism has been reported in the literature. For example, Fernandes et al. (1999) reported a mutualistic relationship between three ant species (Formica neurofibarbis, Liometopium apiculatum, and Monomotium cyaneum) and the gall-forming wasp Disholcaspis edura that coexist in Q. turbinella canopy. The authors found that in the presence of ants, galls with the largest diameter suffered a lower mortality rate due to Platigaster sp. parasitoid attack. Thus, presence of ants reduced the selective pressure imposed by the parasitoid on wasp galls. Also, the occurrence of ecosystem engineers has been reported in oak canopy community structure literature. An example is the study of Lill and Marquis (2003) who examined the effect of shelterbuilding caterpillars Pseudotelphusa sp. (Gelechiidae) on the species richness and guild structure of leafchewing herbivores occupying individual white oak (Quercus alba) samplings in Missouri. The authors found that the availability of leaf shelters created by Pseudotelphusa sp. within a tree's canopy is an important organizing factor because the species richness of the associated insect herbivore community was determinate. Similarly, Wang et al. (2012) using two species of leaf-tying caterpillars Pseudotelphusa quercinigracella and Psilocorsis cryptolechiella found that the presence of leaf ties increased species density and abundance of herbivores, predators, and scavengers, depending on the oak host species (Q. alba, Q. imbricaria, Q. macrocarpa, Q. marilandica, Q. muehlenbergii, Q. velutina, Q. rubra, and Q. stellata). Also, arthropod species composition differed between untied leaves and between ties made by the two leaf-tier species.

These associations among organisms across multiple trophic levels (Hooper et al. 2000; Sutherland 2006) may be mediated through "bottom-up" processes whereby diversity at higher trophic levels is governed by diversity at lower trophic levels or "top-down" control, via consumption by higher trophic levels (Hunter and Price 1992). Now, it is generally accepted that bottom-up and top-down forces act in concert to influence populations of most phytophagous insects (Hartvigsen et al. 1995; Hunter et al. 1997; Denno et al. 2002; Schönrogge et al. 2013). For example, temporal variation in the abundance of winter moth on oak trees in England depends largely upon the delayed density-dependent interaction of the herbivore with its natural enemies, a top-down effect (Hunter et al. 1997). In contrast, spatial variation in winter moth abundance among individual trees depends largely upon the density-independent effect of hostplant phenology, a bottom-up force. More recently, Schönrogge et al. (2013) quantified spatial patterns in native bird predation of invading gall inducing Andricus wasps associated with introduced Turkey oak (Quercus cerris) at eight sites across the UK. They found variation in gall density among trees driven by bottom-up influences of host oak (genotype) and simultaneously, a topdown regulation by birds of gall wasp populations.

In particular, researchers now readily acknowledge that interactions between plants, herbivores and natural enemies are commonplace (Forkner and Hunter 2000; Denno et al. 2002). Thus, host plants can impact herbivores directly by influencing their performance and survival (Lill and Marquis 2001; Sobek et al. 2009) and indirectly by mediating the effects of natural enemies (Lawton and McNeill 1979; Price et al. 1980). On the other hand, predators frequently have important influences on ecosystems through direct effects on the regulation of herbivorous insects densities and indirect effects propagated to primary producers (i.e., Marquis and Whelan 1994; Van Bael et al. 2003; Mäntylä et al. 2011). Finally, these relationships between species across different trophic levels may have effects on the 
community structure and ecosystem functioning (Kagata and Ohgushi 2006; van Dam and Heil 2011).

Interactions involving plants, herbivores, and predators have been reported in oaks and the consequences for arthropod communities have been variables. For example, Marquis and Welan (1994) revealed that the presence of three species of birds (Polioptila caerulea, Regulus calendula, and $R$. satrapa) enhances the growth of juveniles oaks of $Q$. alba via birds consumption of leaf-chewing insects (Lepidoptera: Catocala amica) in Missouri, USA. On the other side, Fernandes et al. (1999) reported that the interaction between ants (Formica neurofibarbis, Liometopium apiculatum, and Monomotium cyaneum) and gall wasps (Disholcaspus sp.) in Quercus turbinella canopy in Arizona, USA, reduced nearly half of the parasitism rate exercised by the parasitoid Platygaster sp. on galls of $D$. edura. In both studies, it is suggested that the third trophic level influences the population density of herbivorous insects but in an opposite direction. On the other hand, control bottom-up regulated by the heterogeneity in plant productivity and quality (i.e., nutrient availability, plant chemistry) has been recognized on the arthropod community structure associated to oaks. For example, Forkner and Hunter (2000) evaluated the importance of interactions bottom-up vs. top-down on $Q$. rubra and $Q$. prinus canopy insect communities. In this study, it was found that herbivorous insects were more abundant in plants of better quality (nitrogen, gallotannins, proanthocyanidins), and in response, predaceous insects were also more abundant. In contrast, exclusion of predators (birds) had not detectable effect on the presence or absence of herbivores or predaceous insects. The authors suggested that in these insect communities associated to oak canopies, bottom-up forces appear to regulate to influence the impact of top-down forces.

Finally, phytophagous insects frequently interact with pathogens within local communities (Hatcher 1995; Simon and Hilker 2003; Stout et al. 2006). Despite this fact, Stout et al. (2006) concluded in a review that pathogen-plant-insect interactions still receive limited attention. Most notably, few studies have examined interactions between plant-feeding insects and plant pathogens in the field or placed such interactions in a wider community context (Stout et al. 2006), oaks are no exception. In the literature, there are few studies that have addressed interactions between plant pathogens and herbivores. For example, Tack et al. (2012) evidence the interactions between three plant-feeding guilds: leaf miners, free-feeding insects, and the oak powdery mildew (Erysiphe alphitoides) in Q. robur canopy in Finland. The authors reported that individual species of insects responded differently to the intensity of pathogen infection and that the presence of the leaf miner T. ekebladella on oak leaves infected by powdery mildew decreased the abundance of parasitoids emerging from these leaves in the following year. Both results suggest that mildew may drive the relative abundances of different species in different directions, thereby molding the structure of the full community.

We concluded that interactions between species are forces that influence the distribution, diversity, and abundances of arthropods associated to oak canopies and that these may act through different trophic levels in bottom-up and top-down directions. However, the outcome of individual interactions can range from positive or negative from the perspective of each involved species.

\section{Disturbances}

A disturbance has been defined as a discrete event that alters the structure of populations, communities, and ecosystems changing the availability of resources and conditions (White and Pickett 1985). Because disturbances are ecological processes that promote succession, producing vegetation mosaics with different degrees of structural complexity (White and Pickett 1985), they may alter the composition of the communities and the spatial patterns of diversity (Fagan et al. 1999; Cantrell et al. 2001). Specifically, the intensity, frequency, duration, and area of disturbance can determine the abundance and species richness in the communities (Huston 1994; Townsend et al. 1997). In general, temperate and tropical forests are subject to the effect of natural disturbances such as fire, storms, hurricanes, and floods (Dziock et al. 2006; Martikainen et al. 2006), and of anthropogenic disturbances such as deforestation, agriculture, and urbanization (Hirao et al. 2007). In particular, this review addresses the effect of anthropogenic disturbances on the structure of communities associated with the canopy of oaks.

To date, there are several studies in tropical and temperate zones that have evaluated how human disturbances, in various forms and with different intensities is affecting the arthropod communities associated with the canopy (Hill et al. 1995; Ozanne et al. 1997, 2000; Floren and Linsenmair 2001, 2003; Tovar-Sánchez et al. 2003; Floren and Deeleman-Reinhold 2005; Forkner et al. 2006; Müller and Goßner 2007). However, these studies have shown inconsistent results, reporting that a disturbance can have a negative, positive, or no effect on the structure of arthropod communities. It has been suggested that these results can in part be explained by differences in dispersal abilities, habitat requirements, distribution patterns of different species of arthropods (Cooke and Roland 2000), as well as by differences in the historical factors and heterogeneity of the site (Hamer et al. 2003) and the scale and degree of the disturbance (Lewis 2001). 
In particular, temperate forests are characterized by their diversity, richness, and longevity (Challenger 1998). Much of this diversity is found in the canopy, and arthropods constitute a major fraction of this species pool (Stork and Hammond 1997). Unfortunately, temperate forests are being converted into monoculture plantations and agricultural land, increasing the dominance of human activity on the landscape; the resulting fragmentation of forests has caused a marked decrease in biodiversity (Kimmins 1997; Maleque et al. 2006). Particularly, it has been suggested that canopy arthropods can be considered indicators of forest condition because they respond quickly to changes in environmental conditions (Schowalter 1995; Ozanne et al. 1997; Maleque et al. 2006, 2009).

Studies on the effect of disturbances on the canopy arthropod fauna associated to oaks have also shown conflicting results. On the one hand, there are studies like that of Tovar-Sánchez et al. (2003), who compared three forests with different degrees of disturbance and found a significant decrease in the abundance and diversity of ectophagous canopy arthropods associated to Q. castanea, Q. crassipes, Q. crassifolia, Q. greggii, Q. laeta, and Q. rugosa in the Valley of Mexico, in response to the disturbance gradient across forests. Similar responses were reported for the richness of herbivores associated with the canopy of $Q$. alba and for the richness and abundance of leaf-chewing insects associated with the canopy of $Q$. alba and Q. velutina in Missouri (Forkner et al. 2006, 2008).

Moreover, other studies reported that oak canopy arthropods did not respond to the disturbances. Such is the case of the beetles associated with the canopy of Quercus spp. in forest fragments with different degrees of urbanization (rural-suburban-urban); in this case, the composition and species richness did not differ in response to a gradient of disturbance in Bulgaria (Niemelä et al. 2002). The authors suggest that the beetles were not affected because the magnitude of the habitat disturbance in this gradient was moderate or because local factors such as temperature, moisture, and soil conditions determined the results.

As mentioned above, disturbances are environmental events that trigger the succession process of forests (White and Pickett 1985); thus, different studies have focused on the study of the succession process of plants following a disturbance (Jeffries et al. 2006); however, relatively little is known about the responses of arthropod communities to the succession process of their host plants (Morin 1999). It has been proposed that changes in the characteristics of plant communities as a result of a disturbance can influence arthropod communities, particularly if these specialize on certain species of host plants or on microhabitats generated by a particular form of plant growth (Jeffries et al. 2006). In general, forests in late successional stages have greater structural complexity compared to young forests or plantations (Ishii et al. 2004); this is because the former have larger trees in terms of height, biomass, and structural complexity providing a more complex architecture of young forests (Schowalter 1995; Evans and Jukes 2000; Jeffries et al. 2006).

Studies in oaks on this topic are scarce; however, the few studies that have been conducted showed that the age of the forest does have an effect on the community structure of canopy arthropods in terms of richness, diversity, and density. For example, Summerville and Crist $(2002,2003)$ found a decrease in species richness and changes in the composition of the community of Lepidoptera associated with the canopy of Quercus spp. among forests in different successional stages (recently cleared vs. uncleared). Similarly, Jeffries et al. (2006) found that the diversity and density of leaf-chewing herbivorous insects (larvae of microlepidoptera, orthoptera, coleoptera, hymenoptera, and phasmids) were higher in the canopy of $Q$. alba in forests of 313 years of age, compared to sites recently affected by disturbances ( 2 years old). In both cases, the authors suggest that changes in the structure of these communities were the result of a shift of the forests to early successional stages.

\section{Implications for conservation}

Natural communities have been considered complex ecological systems whose structure and functioning are determined by the interaction of different factors that vary spatially and temporally (Bailey and Whitham 2006). In the previous sections, we discussed how oak canopy arthropods can respond to changes in genetic, architectural, chemical, phenological, successional factors, etc. and the influence of such factors in the establishment, organization, and maintenance of their communities. Under a conservation perspective, the sensitivity of this group of organisms is important because it suggests the role of arthropods as indicators of changes in the coverage, structure, and composition of forests. This condition may be the result of two particular attributes of arthropods: a short life cycle and little resilience (Brown 1997). Both features make these animals highly sensitive to changes in the parameters of the ecosystems in which they inhabit; thus, it has been suggested that in addition to their functional importance and contributions to biodiversity, arthropods can be very useful as an efficient early warning system for changes in habitat characteristics (Kremen et al. 1993; Schowalter 1995, Ozanne et al. 1997; Maleque et al. 2006, 2009). In this way, canopy arthropods could be useful to predict the consequences of climate change, disturbances, 
or the loss of genetic diversity in oak forests. The use of canopy arthropods to examine the dynamics of the forest as well as alterations in vegetation cover by humans can be an efficient tool in time and cost compared to a longerterm perspective that implies information about palaeoecological record, pollen-based vegetation modeling, and biome reconstruction and global climate simulations (i.e., Feurdean et al. 2015).

Unfortunately, animal conservation strategies have focused on the preservation of species of mammals, birds, and terrestrial or aquatic vertebrates, groups of charismatic animals for which there are many ecological studies documenting the hazards faced by their habitats. This information has been helpful in implementing conservation and management programs (Leather et al. 2008). In contrast, efforts towards the conservation of arthropods have been limited, probably because many species have not been described or because their life history or their role within their communities (Redak 2000) is unknown. However, recent estimates suggest that this group contains the greatest diversity of species on earth (Hamilton et al. 2013), in addition to representing a group of vital organisms for the maintenance of a wide variety of processes at the level of communities and ecosystems, acting as pollinators, herbivores, or predators and participating in decomposition, nutrient cycling, energy transfer, or soil formation (McIntyre et al. 2001). This suggests that the loss of biodiversity of arthropods could have catastrophic consequences in ecological terms. Fortunately, in recent years, it has been proposed that the conservation of biodiversity must be carried out under an integrated approach that includes not only the conservation of unique species but also the conservation of their habitat and ecosystem processes (Bangert et al. 2005). This new approach may be essential to improve our ability to generate efficient conservation strategies (Wimp et al. 2004); in this sense, conserving the habitats and ecosystem processes of oak forests could benefit the arthropod communities associated with their canopy.

\section{Conclusions}

The canopy has been recognized for its important role in the functioning of terrestrial ecosystems and the maintenance of biodiversity. Arthropods constitute a major fraction of the species that inhabit this environment and oaks are one of the plant groups most representative of temperate forests worldwide. Despite this, we conclude that there is a lack of literature that addresses the study of arthropod communities associated with the oak canopies. There are still many aspects that haven't been addresed, which prevents us from making generalizations about some of the patterns found.

In general, the existing studies have revealed that the canopy of oaks supports arthropod communities with high levels of diversity, that this diversity is the result of the great genetic, morphological, chemical, temporal, and spatial variation presented by this group of trees and shrubs, and that this heterogeneity can be observed at different levels: among individuals, species, localities, or regions. Most of these studies have focused on the response of the phytophagous insects of the Coleoptera, Hymenoptera, and Lepidoptera orders to changes in their host oaks. Research topics have been varied; however, most studies have focused on the effect of seasonal, spatial, and chemical variations in the host plant on the structure of arthropod communities, as well as on the effect of the hybridization of host plants on the resistance patterns of arthropods. The least studied aspects have been the effect of genetic diversity and of the origin (native vs. introduced) of the host oak. This review allowed us to find a lack of standardization in sampling and collection techniques, as well as inconsistencies in the criteria for defining the structure of the canopy. We also found that the existing studies did not consider variables such as habitat preference, type of feeding (guilds), or stage of development of the arthropods studied, which prevents generalizations about the patterns found. Furthermore, we could detect a bias towards the study of phytophagous insects and a lack of studies in other important groups such as acorn weevils, whose activity has an impact on the fitness and dispersion of host plants.

As a result of this review, we can conclude that the study of the arthropod fauna associated to oak canopy is a huge field of research to be explored, considering the large number of oak species that exist worldwide and the enormous diversity of arthropods that inhabit their canopy. As the knowledge of how the canopy arthropod communities respond to changes in their surrounding habitat moves forward, these animals may be recognized as bioindicators of oak forests health.

Competing interests

The authors declare that they have no competing interests.

\section{Authors' contributions}

Both authors participated in the review topic design, in the data analyses, and in the manuscript writing. Both authors read and approved the final manuscript.

\section{Acknowledgements}

This research was supported by a scholarship from CONACYT-SEP Mexico to L.V.C. We thank Dr. Gabriela Castaño Meneses for her critical comments on the manuscript. We also thank the Posgrado en Ciencias Biológicas (UNAM) and Centro de Investigaciones en Biodiversidad y Conservación (CIByC, UAEM).

Received: 12 April 2015 Accepted: 6 August 2015

Published online: 18 August 2015

\section{References}

Abrahamson WG, Melika MD, Scrafford R, Csóka P (1998) Gall-inducing insects provide insights into plant systematic relationship. Am J Bot 85:1159-1165 
Abrahamson WG, Hunter MD, Melika G, Price PW (2003) Cynipid gall-wasp communities correlate with oak chemistry. J Chem Ecol 29:209-223

Adis J, Basset Y, Floren A, Hammond PM, Linseinmar KE (1998) Canopy fogging an overstory tree-recommendations for standardization. Ecotropica 4:93-97

Affeld K (2008) Spatial complexity and microclimatic responses of epiphyte communities and their invertebrate fauna in the canopy of northern rata (Metrosideros robusta A. Cunn.: Myrtaceae) on the West Coast of the South Island, New Zealand. PhD. Thesis. Lincon University, Canterbury

Agrawal AA, Kotanen PM (2003) Herbivores and the success of exotic plants: a phylogenetically controlled experiment. Ecol Lett 6:712-715

Agrawal AA, Kotanen PM, Mitchell CE, Power AG, Godsoe W, Klironomos J (2005) An experiment with congeneric plant pairs and diverse above and belowground enemies. Ecology 86:2979-2989

Agrawal AA, Lau JA, Hambäck PA (2006) Community heterogeneity and the evolution interactions between plants and insect herbivores. Q Rev Biol 81:349-376

Aguilar JM, Boecklen WJ (1992) Patterns of herbivory in the Quercus grisea X Quercus gambelii species complex. Oikos 64:498-504

Atauri JA, Lucio JV (2001) The role of landscape structure in species richness distribution of birds, amphibians, reptiles and lepidopterans in Mediterranean landscapes. Land Ecol 16:147-159

Auerbach M, Simberloff D (1988) Rapid leaf-miner colonization of introduced trees and shifts in sources of herbivore mortality. Oikos 52:41-50

Avise JC (1994) Molecular markers, natural history and evolution. Chapaman and Hall, New York, N.Y

Bailey JK, Wooley SC, Lindroth RL, Whitham TG (2006) Importance of species interactions to community heritability: a genetic basis to trophic level interactions. Ecol Lett 9:78-85

Bangert RK, Turek RJ, Martinsen GD, Wimp GM, Bailey JK, Whitham TG (2005) Benefits of conservation of plant genetic diversity on arthropod diversity. Conserv Biol 19:379-390

Bangert RK, Allan GJ, Turek RJ, Wimp GM, Meneses N, Martinsen GD, Keim P, Whitham T (2006) From genes to geography: a genetic similarity rule for arthropod community structure at multiple geographic scales. Mol Ecol $15: 4215-4228$

Bangert RK, Whitham TG (2007) Genetic assembly rules and community phenotypes. Evol Ecol 21:549-560

Bangert RK, Lonsdorf EV, Wimp GM, Shuster SM, Fisher D, Schweitzer JA, Allan GJ, Bailey JK, Whitham TG (2008) Genetic structure of a foundation species: scaling community phenotypes from the individual to the region. Heredity 100:121-131

Barbenhenn RV, Martin MM (1994) Tannin sensitivity in larvae of Malacossomadisstira (Lepidoptera): roles of the peritrophic envelope and midgut oxidation. J Chem Ecol 20:1985-2001

Barber NA, Marquis RJ (2009) Spatial variation in top-down direct and indirect effects on white oak (Quercus alba L.). Am Midland Nat 162:169-179

Basset $Y$ (1991) The taxonomic composition of the arthropod fauna associated with an Australian rainforest tree. Aust J Zool 39:171-190

Basset Y, Aberlenc HP, Delvare G (1992) Abundance and stratification of foliage arthropods in a lowland rainforest of Cameroon. Ecol Entomol 17:310-318

Basset $Y$, Novotny $V$ (1999) Species richness of insect herbivore communities on Ficus in Papua New Guinea. Biol J Linn Soc 67:477-499

Basset Y, Horlyck V, Wright J (2003a) Forest canopies and their importance. In: Basset $Y$, Horlyck V, Wright J (eds) Studying forest canopies from above: the international canopy crane network. Smithsonian Tropical Research Institute. UNEP, Panama City, pp 27-33

Basset Y, Novotny N, Miller SE, Kitching RL (2003b) Methodological advances and limitations in canopy entomology. In: Basset $Y$, Novotny $V$, Miller S, Kitching $\mathrm{RL}$ (eds) Arthropods of tropical forest. Spatio-temporal dynamics and resource use in the canopy. Chapman and Hall, London, pp 7-16

Basset Y, Corbara B, Barrios H, Cuénoud P, Leponce M, Aberlenc H, Bail J, Bito D, Bridle JR, Castaño-Meneses G, Cizek L, Cornejo A, Curletti G, Delabie JHC, Dejean A, Didham RK, Dufrêne M, Fagan LL, Floren A, Frame DM, Hallé F, Hardy OJ, Hernandez A, Kitching RL, Lewinsohn TM, Lewis OT, Manumbor E, Medianero E, Missa O, Mitchell AW, Mogia M, Novotny V, Ødegard F, Oliveira E, Orivel J, Ozanne CMP, Pascal O, Pinzón S, Rapp M, Ribeiro S, Roisin Y, Roslin T, Roubik W, Samaniego M, Schmidl J, SØrensen LL, Tishechkin A, Van Osselaer C, Winchester NN (2007) IBISCA-Panama, a large-scale study of arthropod beta-diversity and vertical stratification in a lowland rainforest: rationale, study sites and field protocols. Bull Inst R SC N B-E 77:39-69

Bailey JP, Whitham T (2006) Interactions between cottonwood and beavers positively affect sawfly abundance. Ecol Entomol 31:294-297
Beals ML (2006) Understanding community structure: a data-driven multivariate approach. Oecologia 150:484-495

Becerra JX, Venable DL, Evans PH, Bowers WS (2001) Interactions between chemical and mechanical defenses in the plant genus Bursera and their implications for herbivores. Am Zool 41:865-876

Begon M, Townsend CR, Harper JL (2005) From individuals to ecosystems. Blackwell Publishers, Hoboken

Bernays EM, Graham M (1988) On the evolution of host specificity in phytophagous arthropods. Ecology 69:886-892

Bertness MD, Callaway RM (1994) Positive interactions in communities. Trends Ecol Evol 9:191-193

Boecklen WJ, Spellenberg R (1990) Structure of herbivore communities in two oak (Quercus spp.) hybrid zones. Oecologia 85:92-100

Boege K (2004) Herbivore attack in Casearia nitida influenced by plant ontogenetic variation in foliage quality and plant architecture. Oecologia 143:117-125

Böhm SM, Wells K, Kalko EKV (2011) Top-down control of herbivory by birds and bats in the canopy of temperate broad-leaved oaks (Quercus robur). PLoS One 6(4), e17857. doi:10.1371/journal.pone.0017857

Bronstein JL (1994) Our current understanding of mutualism. Q Rev Biol 69:31-51

Brown KS (1997) Diversity, disturbance, and sustainable use of Neotropical forests: insects as indicators for conservation monitoring. J Insect Conserv $1: 25-42$

Brown JL, Vargo S, Connor EF, Nuckols MS (1997) Causes of vertical stratification in the density of Cameraria hamadryadella. Ecol Entomol 22:16-25

Burchsted D, Daniels M, Thorson R, Vokoun J (2010) The river discontinuum: applying beaver modifications to baseline conditions for restoration of forested headwaters. BioScience 60:908-922

Campos RI, Vasconcelos HL, Ribeiro SP, Neves FS, Soares JP (2006) Relationship between tree size and insect assemblages associated with Anadenanthera macrocarpa. Ecography 29:442-450

Cantrell RS, Cosner C, Fagan WF (2001) Brucellosis, botflies and brainworms: the impact of edge habitats on pathogen transmission and species extinction. J Math Biol 42:95-119

Castagneyrol B, Lagache L, Giffard B, Kremer A, Jactel H (2012) Genetic diversity increases insect herbivory on oak saplings. PLoS One 7(8), e44247

Ceia RS, Ramos JA (2014) Birds as predators of cork and holm oak pests. Agrofores Syst: 1-18. doi:10.1007/s10457-014-9749-7.

Challenger A (1998) Utilización y conservación de los ecosistemas terrestres de México: Pasado, presente y futuro. Instituto de Biología \& CONABIO, Mexico

Cheng D, Vrieling K, Klinkhammer PGL (2011) The effect of hybridization on secondary metabolites and herbivore resistance: implications for the evolution of chemical diversity in plants. Phytochem Rev 10:107-117

Colautti RI, Ricciardi A, Grigorovich IA, Maclsaac HJ (2004) Is invasion success explained by the enemy release hypothesis? Ecol Lett 7:721-733

Coley PD, Barone JA (1996) Herbivory and plant defenses in tropical forest. Ann Rev Ecol Syst 27:305-335

Coley PD, Bateman LM, Kursar A (2006) The effects of plant quality on caterpillar growth and defense against natural enemies. Oikos 115:218-228

Connor RC (1995) The benefits of mutualism: a conceptual framework. Biol Rev 70:427-457

Cooke BJ, Roland J (2000) Spatial analysis of large-scale patterns of forest ten caterpillar outbreaks. Ecoscience 7:410-422

Cornelissen T, Stiling P (2006) Responses of different herbivore guilds to nutrient addition and natural enemy exclusion. Ecoscience 13:66-74

Cornelissen T, Stiling P (2008) Cumpled distribution of oak leaf mines between and within plants. Basic Appl Ecol 96:7-77

Cripps MG, Schwarzländer M, McKenney JL, Hinz HL, Price WJ (2006) Biogeographical comparison with Lepidium draba in its native, expanded and introduced ranges. J Biogeo 33:2107-2119

Crutsinger GM, Souza L, Sanders NJ (2008) Intraspecific diversity and dominant genotypes resist plant invasions. Ecol Lett 11:16-23

Curtu AL, Gailing O, Finkeldey R (2007) Evidence for hybridization and introgression within a species-rich oak (Quercus spp.) community. BMC Evol Biol 7:218

Denno RF, McClure MS, Ott JR (1995) Interspecific interactions in phytophagous insects: competition reexamined and resurrected. Ann Rev Entomol 40:297-331

Denno RF, Gratton C, Peterson MA, Langellotto GA, Finke DL, Huberty AF (2002) Bottom-up forces mediate natural-enemy impact in a phytophagous insect community. Ecology 83:1443-1458 
Dungey HS, Potts BM, Whitham TG, Li H-F (2000) Plant genetics affects arthropod community richness and composition: evidence from a synthetic eucalypt hybrid population. Evolution 54:1938-1946

Dziock F, Henle K, Follner F, Scholz M (2006) Biological indicators systems in floodplains-a review. Int Rev Hydrobiol 191:292-313

Ellison AM, Bank MS, Clinton BD, Colburn EA, Elliott K, Ford CR, Foster DR, Kloeppel BD, Knoepp JD, Lovett GM, Mohan J, Orwig DA, Rodenhouse NL, Sobczak WV, Stinson KA, Stone JK, Swan CM, Thompson J, Von Holle B, Webster JR (2005) Loss of foundation species: consequences for the structure and dynamics of forested ecosystems. Front Ecol Environ 3:479-486

Erwin TL (1982) Tropical forests: their richness in Coleoptera in another arthropod species. Coleopts Bull 36:74-75

Erwin TL (1995) Measuring arthropod biodiversity in the tropical forest canopy. In: Lowman ED, Nadkarni N (eds) Forest Canopies. Academic Press, San Diego, pp 109-127

Evans HF, Jukes MR (2000) The role of niche availability as a factor determining the diversity and abundance of invertebrates on Scots pine, Pinus sylvestris. Investigaciones Agrarias: Sistemas y Recursos Forestales Fuera de Series no. 1-2000:273-295

Faeth SH, Bultman TL (1986) Interacting effects of increased tannin levels on leafmining insects. Entomol Exp App 40:297-300

Fagan WF, Cantrell RS, Cosner C (1999) How habitat edges change interactions. Am Nat 153:165-182

Feeny P (1970) Seasonal changes in oak leaf tannins and nutrients as a cause of spring feeding by winter moth caterpillars. Ecology 51:565-581

Fernandes GW, Fagundes M, Woodman RL (1999) Ant effects on three-trophic level interactions: plants, galls and parasitoids. Ecol Entomol 24:411-415

Fisher RA (1930) The general theory of natural selection. University, Press, Oxford

Floate KD, Whitham TG (1993) The "hybrid bridge" hypothesis: host shifting via plant hybrid swarms. Am Nat 4:651-652

Floren A, Linsenmair KE (2001) The influence of anthropogenic disturbance on the structure of arboreal arthropod communities. Plant Ecol 153:153-167

Floren A, Linsenmair KE (2003) How do beetle assemblages respond to anthropogenic disturbance? In: Basset Y, Novotny V, Miller SE, Kitching R (eds) Arthropods of Tropical Forests: spatio-temporal dynamics and resource use in the canopy. University Press, Cambridge, pp 190-197

Floren A, Deeleman-Reinhold C (2005) Diversity of arboreal spiders in primary and disturbed tropical forests. J Arachnol 33:323-333

Forkner RE, Hunter MD (2000) What goes up must come down? Nutrient and predation pressure on oak herbivores. Ecology 81:1588-1600

Forkner RE, Marquis RJ, Lill JT (2004) Feeny revisited: condensed tannins as anti-herbivore defenses in leaf-chewing herbivore communities of Quercus. Ecol Entomol 29:174-187

Forkner RE, Marquis RJ, Lill JT, Le Corff J (2006) Impacts of alternative timber harvest practices in leaf-chewing herbivores of oak. Conserv Biol 20:429-440

Forkner RE, Marquis RJ, Lill JT, Corff JL (2008) Timing is everything? Phenological synchrony and population variability in leaf-chewing herbivores of Quercus. Ecol Entomol 33:276-285

Feurdean A, Marinova E, Nielsen AB, Liakka J, Veres D, Hutchinson SM, Braun M, TimarGabor A, Astalos C, Mosburgger V, Hickler T (2015) Origin of the forest steppe and exceptional grassland diversity in Transylvania (central-eastern Europe). J Biogeogr 42:951-963

Frenzel M, Brandl R (2003) Diversity and abundance patterns of phytophagous insect communities on alien and native host plants in the Brassicaceae. Ecography 26:723-730

Fritz RS, Roche BM, Brunsfeld SJ (1998) Genetic variation in a resistance of hybrid willows to herbivore. Oikos 83:117-128

Fritz RS, Nichols-Orians CM, Brunsfeld SJ (1994) Interspecific hybridization of plants and resistance to herbivores: hypotheses, genetics, and variable responses in a diverse community. Oecologia 97:106-117

Fritz RS, Roche BM, Brunsfeld SJ, Orians CM (1996) Interespecific and temporal variation in herbivores responses to hybrid willows. Oecologia 108:121-129

Fritz RS (1999) Resistance of hybrid plants to herbivores: genes, environment, or both? Ecology 80:382-391

Gaston KJ (1991) Regional numbers of insect and plant species. Funct Ecol 6:243-247

Gaston KJ, Reavey D, Valladares GR (1992) Intimacy and fidelity: intermedial and external feeding by the British microlepidoptera. Ecol Entomol 17:86-88

Gaston K (2000) Global patterns in biodiversity. Nature 405:220-227

Gering JC, Crist TO (2000) Patterns of beetle (Coleoptera) diversity in crowns of representative tree species in an old-growth temperate deciduous forest. Selbyana 21:38-47
Gering JC, Veech JA, Crist TO (2003) Additive partitioning of species diversity across multiple spatial scales: implications for regional conservation of biodiversity. Conserv Biol 17:488-499

Glynn C, Rönnberg-Wästljun A, Julkunen-Tiitto R, Weih M (2004) Willow genotype, but not drought treatment, affects foliar phenolic concentrations and leaf-beetle resistence. Entomol Exp Appl 113:1-14

González-Rodríguez A, Arias DM, Valencia S, Oyama K (2004) Morphological and RAPD analysis of hybridization between Quercus affinis and Quercus laurina (Fagaceae), two Mexican red oaks. Am J Bot 91:401-409

Govaerts R, Frodin DG (1998) World checklist and bibliography of Fagales (Betulaceae, Corylaceae, Fagaceae and Ticodendraceae). Royal Botanic Gardens, Kew, UK

Gunnarsson B, Hake M (1999) Bird predation affects canopy-living arthropods in city parks. Can J Zool 77:1419-1428

Gurevitch J, Scheiner SM, Fox GA (2002) The ecology of plants. Sinauer Associates, Sunderland (MA)

Halaj J, Ross DW, Moldenke AR (2000) Importance of habitat structure to the arthropod food-web in Douglas fir canopies. Oikos 90:139-152

Hamer KC, Hill JK, Benedick S, Mustaffa N, Sherratt TN, Maryati M, Chey VK (2003) Ecology of butterflies in natural and selectively logged forests of northern Borneo: the importance of habitat heterogeneity. J Appl Ecol 40:150-162

Hamilton AJ, Novotny V WEK, Bassset Y, Benke KK, Grimbacher PS, Samuelson GA, Weiblen GD, Yen JDL, Stork NE, Weiblen GD, Yen JDL (2013) Estimating global arthropod species richness: refining probabilistic models using probability bounds analysis. Oecologia 171:357-365

Hansen RA (2000) Effects of habitat complexity and composition on a diverse litter microarthropod assemblage. Ecology 81:1120-1132

Hartvigsen G, Wait DA, Coleman JS (1995) Tri-trophic interactions influenced by resource availability: predator effects on plant performance depend on plant resources. Oikos 74:463-468

Hastings A, Byers JE, Crooks JA, Cuddington K, Jones CG, Lambrinos JG, Talley TS, Wilson WG (2007) Ecosystem engineering in space and time. Ecol Lett 10:153-164

Hatcher PE (1995) Three-way interactions between plant pathogenic fungi, herbivorous insects and their host plants. Biol Rev 70:639-694

Henriksson J, Haukioja E, Ossipova V, Sillampää S, Kapari L, Pihlaja K (2003) Effects of host shading on consumption and growth of the geometrid Epirrita autunmata: interactive roles of water, primary and secondary compounds. Oikos 103:3-16

Hersch-Green El, Turley NE, Johnson MTJ (2011) Community genetics: what have we accomplished and where should we be going. Phil Trans Roy Soc B 366:1453-1460

Hill JKK, Hamer KC, Lace LA, Banham MT (1995) Effects of selective logging on tropical forest butterflies on Buru, Indonesia. J Applied Ecol 32:754-760

Hill SB, Kotanen PM (2010) Phylogenetically structured damage to Asteraceae: susceptibility of native and exotic species to foliar herbivores. Biol Invasions 12:3333-3342, Online publication: 27 February 2010

Hirao T, Murakami M, Kashizaki A, Ichtanabe S (2007) Additive apportioning oflepidopteran and coleopteran species diversity across spatial and temporal scales cool-temperate deciduous forest in Japan. Ecol Entomol 32:627-636

Hochwender CG, Fritz RS (2004) Plant genetic differences influence herbivore community structure evidence from a hybrid willow system. Oecologia 138:547-557

Hooper DU, Bignell DE, Brown BK, Brussaard L, Dangerfield JM, Wall DH, Wardle VD, Coleman DC, Giller EK, Lavelle P, Van Der Putten WH, De Ruiter PC, Rusek J, Silver WL, Tiedje JM, Wolter V (2000) Interactions between aboveground and belowground biodiversity in terrestrial ecosystems: patterns, mechanisms and feedbacks. Bioscience 50(12):1049

Howard DJ, Preszler RW, Williams J, Fenchel S, Boecklen WJ (1997) How discrete are oak species? Insights from a hybrid zone between Quercus grisea and Quercus gambelii. Evolution 51:747-755

Hughes R, Inouye BD, Johnson MTJ, Underwood N, Vellend M (2008) Ecological consequences of genetic diversity. Ecol Lett 11:609-623

Humphrey JW, Hawes C, Pearce AJ, Ferris-Khan R, Jukes MR (1999) Relationships between insect diversity and habitat complexity and plantation forest. For Ecol Manage 113:11-21

Hunter MD, Price PW (1992) Playing chutes and ladders: heterogeneity and the relative roles of bottom-up and top-down forces in natural communities. Ecology $73: 723-732$

Hunter MD, Varley GC, Gradwell GR (1997) Estimating the relative roles of top-down and bottom-up forces on insect herbivore populations: a classic study revisited. Proc Natl Acad Sci U S A 94:9176-9181 
Hurtado JC, da Fonseca CRV, Hammond PM, Stork NE (2003) Seasonal variation of canopy arthropods in Central Amazonian. In: Basset $Y$, Novotny $V$, Miller SE, Kitching R (eds) Arthropods of Tropical Forests: spatio-temporal dynamics and resource use in the canopy. Chapman \& Hall, London, pp 170-175

Huston MA (1994) Biological diversity: the coexistence of species on changing landscapes. Cambridge University Press, Cambridge, UK

Inoue T (2003) Chronosequential change in a butterfly community after clear-cutting of deciduous forest in a cool temperate region of central Japan. Entomol Sci 6:151-163

Ishida T, Hattori K, Sato H, Kimura MT (2003) Differentiation and hybridization between Quercus crispula and Q. dentate (Fagaceae): insights from morphological traits, amplified fragment length polymorphism markers, and leafminer composition. Am J Bot 90:769-776

Ishii HT, Tanabe S, Hiura T (2004) Exploring the relationships among canopy structure, stand productivity and biodiversity of temperate forest ecosystems. For Sci 50:342-355

Ito M, Ozaki K (2005) Response of a gall wasp community to genetic variation in the host plant Quercus crispula: a test using half-sib families. Acta Oecol 27:17-24

Janzen DH (1985) The natural history of mutualisms. In: Boucher DH (ed) The Biology of Mutualism. Oxford University Press, New York, NY, pp 40-99

Jeffries JM, Marquis RJ, Forkner RE (2006) Forest age influences oak insect herbivore community structure, richness and density. Ecol Appl 16:901-912

Jermy T (1984) Evolution on insect/host plant relationship. Am Nat 124:609-630

Johnson MTJ, Agrawal AA (2005) Plant genotype and environment interact to shape a diversity arthropod community on evening primrose (Oenothera biennis). Ecology 86:874-885

Johnson MTJ, Stinchcombe JR (2007) An emerging synthesis between community ecology and evolutionary biology. Trends Ecol Evol 22:250-257

Jones CG, Gutiérrez JL (2007) On the purpose, meaning, and usage of the physical ecosystem engineering concept. In: Cuddington K, Byers JE, Wilson WG, Hastings A (eds) Ecosystem engineers: plants to protists. Academic/Elsevier, Amsterdam, pp 3-24

Jones CG, Lawton JH, Shachak M (1997) Positive and negative effects of organisms as physical ecosystem engineers. Ecology 78:1946-1957.

Kagata H, Ohgushi T (2006) Bottom-up trophic cascades and material transfer in terrestrial food webs. Ecol Res 21:26-34

Kaplan I, Denno RF (2007) Interspecific interactions in phytophagous insects revisited: a quantitative assessment of competition theory. Ecol Lett 10:977-994

Karban R, Myers JH (1989) Induced plant responses to herbivory. Ann Rev Ecol Syst 20:331-348

Kause A, Ossipov V, Haukioja E, Lempa K, Hanhimaki S, Ossipova S (1999) Multiplicity of biochemical factors determining quality of growing birch leaves. Oecologia 120:102-112

Keane RM, Crawley MJ (2002) Exotic plant invasions and the enemy release hypothesis. Trends Ecol Evol 17:164-170

Keim P, Paige KN, Whitham TG, Lark KG (1989) Genetic analysis of an interspecific hybrid swarm of Populus: occurrence of unidirectional introgression. Genetics 123:557-565

Kiers ET, Palmer TM, Ives AR, Bruno JF, Bronstain JL (2010) Mutualism in a changing world: an evolutionary perspective. Ecol Lett 13(12):1459-1474

Kimmins JP (1997) Biodiversity and its relationship to ecosystem health and integrity. For Chronics 73:229-232

Kopper BJ, Jakobi VN, Osier TL, Lindroth RL (2002) Effects of paper birch condensed tannin on Whitemarked Tussock moth (Lepidoptera:Lymantriidae) performance. Environ Entomol 31:10-14

Kremen C, Colwell RK, Erwin TL, Murphy DD, Noss RF, Sanjayan MA (1993) Terrestrial arthropod assemblages: their use in conservation planning. Conserv Bio 7:796-808

Kursar TA, Coley PD (2003) Convergence in defense syndromes of young leaves in tropical rainforest. Biochem Syst Ecol 21:929-949

Laitinen M, Julkunen-Titto R, Rousi M (2000) Variation in phenolic compounds within a birch (Betula pendula) population. J Chem Ecol 26:1609-162

Lambert L, McPherson RM, Espelie KE (1995) Soybean host plant resistance mechanisms that alter abundance of white-flies (Homoptera: Alyrodidae) Environ Ecol 24:1381-1386

Larsson SI, Wiren Al, Lundgren LI, Ericsson I (1986) Effects of light and nutrients stress on leaf phenolic chemistry in Salix dasyclados and susceptibility Galerucella lineola (Coleoptera). Oikos 47:205-210

Lassau SA, Hochuli D (2005) Wasp community responses to habitat complexity in Sydney sandstone forest. Austral Ecol 30:179-187
Lawton JH (1982) Vacant niches and unsaturated communities: a comparison of bracken herbivores at sites on two continents. J Anim Ecol 51:573-595

Lawton JH, McNeill S (1979) Between the devil and deep blue sea: On the problem of being a herbivore. In: Anderson RM, Turner BD, Taylor LR (eds) Population dynamics. Symp British Ecol Soc. London. pp 223-244.

Leather SR, Basset Y, Hawkins BA (2008) Insect conservation: finding the way forward. Insect Conserv Diver 1:67-69

Le Corff J, Marquis RJ (1999) Difference between understory and canopy in herbivore community composition and leaf quality for two oak species in Missouri. Ecol Entomol 24:46-58

Lewinsohn TM, Novotny V, Basset $Y$ (2005) Insects on plants: diversity of herbivore assemblages revisited. Annu Rev Ecol Evol Syst 36:597-620

Lewis OT (2001) Effects of experimentals selective logging on tropical butterflies. Conserv Biol 15:389-400

Lichtenberg JS, Lichtenberg DA (2002) Weak trophic interactions among birds, insects and white oak saplings (Quercus alba). Am Mid Nat 148:338-349

Lill JT, Marquis RJ (2001) The effects of leaf quality on herbivore performance and attack from natural enemies. Oecologia 126:418-428

Lill JT, Marquis RJ (2003) Ecosystem engineering by caterpillars increases herbivore diversity on white oak. Ecology 84:682-69

López-Caamal A, Tovar-Sánchez E (2014) Genetic, morphological, and chemical patterns of plant hybridization. Rev Chil Hist Nat 87:16

Lowman MD, Nadkarni NM (1995) Forest canopies. Academic Press, San Diego

Lowman MD (2009) Canopy research in the twenty-first century: a review of arboreal ecology. Trop Ecol 50:125-136

Magri D, Fineschi S, Bellarosa R, Bounamici A, Sebastiani F, Schirone B, Simeone MC, Vendramin G (2007) The distribution of Quercus suber chloroplast haplotypes matches the palaeogeographical history of the western Mediterranean. Mol Ecol 16:5259-5266

Maleque MA, Ishii HT, Maeto K (2006) The use of arthropods as indicators of ecosystem integrity in forest management. J For 104:113-117

Maleque MA, Maeto K, Ishii HT (2009) Arthropods as bioindicators of sustainable forest management, with a focus on plantation forests. Appl Entomol Zool 44:1-11

Manos PS, Stanford AM (2001) The biogeography of Fagaceae: tracking the tertiary history of temperate and subtropical forests of the Northern Hemisphere. Int J Plant Sci 162:S77-S93

Marquis RJ, Whelan CJ (1994) Insectivorous birds increase growth of white oak through consumption of leaf chewing insects. Ecology 75:2007-2014

Marquis RJ, Le Corff J (1997) Estimating pretreatment variation in the oak leafchewing insect fauna of the Missouri Ozark Forest Ecosystem Project (MOFEP). In: Brookshire B, Shifley S (eds) Proceedings of the Missouri Ozark Forest Ecosystem Project Symposium, GTRNC-193. U.S. Department of Agriculture, Forest Service, North Central Experiment Station, St. Paul, Minnesota, USA, pp 332-346

Marquis RJ, Forkner RE, Lill J, Le Corff J (2000) Impact of timber harvest on species accumulation curves for oak herbivore communities of the Missouri Ozarks. Missouri Ozark Forest Ecosystem Project (MOFEP). In: Brookshire B, Shifley S (eds) Proceedings of the Second Missouri Ozark Forest Ecosystem Project Symposium, GTRNC-227. Department of Agriculture, Forest Service, North Central Experiment Station, St. Paul, Minnesota, USA, pp 183-195

Marquis RJ, Lill JT, Piccini A (2002) Effect of plant architecture oncolonization and damage by leaftying caterpillars of Quercus alba. Oikos 99:531-537

Marquis RJ, Lill JT (2010) Impact of plant architecture versus leaf quality on attack by leaf-tying caterpillars on five oak species. Oecologia 163:203-213

Marsico TD, Hellmann JJ, Romero-Severson J (2009) Patterns of seed dispersal and pollen flow in Quercus garryana (Fagaceae) following post-glacial climatic changes. J Biogeogr 36:929-941

Martikainen P, Kouki J, Heikkala O (2006) The effects of green tree retention and subsequent prescribed burning on ground beetles (Coleoptera: Carabidae) in boreal pine-dominated forest. Ecography 29:569-670

Martinsen GD, Whitham TG (1994) More birds nest in hybrid cottonwoods. Wilson Bull 106:474-481

Mattson Jr WJ (1980) Herbivory in relation to plant nitrogen content. Ann Rev Ecol Syst 11:119-161

Mäntylä E, Klemola T, Laaksonen T (2011) Birds help plants: a meta-analysis of top-down trophic cascades caused by avian predators. Oecologia 165:143-152.

Mclntyre NE, Rango J, Fagan WF, Faeth SH (2001) Ground arthropod community structure in a heterogeneous urban environment. Landscape Urban Plan 52:257-274

Mclntyre PJ, Whitham TG (2003) Plant genotype affects long-term herbivore population dynamics and extinction: conservation implications. Ecology $84: 311-322$ 
Meagher RL, Hull LA (1987) Within-tree spatial patterns of Platynota idaeusalis (Lepidoptera: Tortricidae) on two apple cultivars. Environ Entomol 16:786790

Mitchell A (2001) Introduction—canopy science: time to shape up. Plant Ecol 153:5-11

Moffett MW (2000) What's "up"? A critical look at the basic terms of canopy biology. Biotropica 32:569-596

Moran VC, Southwood TRE (1982) The guild composition of arthropods communities in trees. J Anim Ecol 51:289-306

Morin P (1999) Community ecology. Blackwell Science, Oxford, U.K

Müller J, Goßner M (2007) Single host trees in a closed forest canopy matrix: a highly fragmented landscape? J Appl Entomol 131:613-620

Murakami M, Nakano S (2000) Species-specific bird functions in a forest-canopy food web. P Roy Soc Lond B Bio 267:1597-1601

Murakami M, Yoshida K, Hara H, Toda MJ (2005) Spatiotemporal variation in lepidopteran larval assemblages associated with oak Quercus crispula: the importance of leaf quality. Ecol Entomol 30:521-531

Murakami M, Hirao T, Ichie T (2007) Comparison of lepidopteran larval communities among tree species in a temperate deciduous forest, Japan. Ecol Entomol 32:613-620

Murakami M, Ichie T, Hirao T (2008) Beta-diversity of lepidopteran larval communities in a Japanese temperate forest: effects of phenology and tree species. Ecol Res 23:173-189

Murphy SM (2004) Enemy-free space maintains swallowtail butterfly host shift. Proc Natl Acad Sci U S A 101:18048-18052

Nadkarni NM (1994) Diversity of species and interactions in the upper tree canopy of forest ecosystems. Am Zool 34:70-78

Nadkarni NM, Parker GC (1994) A profile of forest canopy science and scientistswho we are, what we want to know, and obstacles we face: results of an international survey. Selbyana 15:38-50

Nadkarni NM (2001) Enhancement of forest canopy research, education, and conservation in the new millennium. Plant Ecol 153:361-367

Nadkarni NM, Parker GG, Rinker HB, Jarzen DM (2004) The nature of forest canopies. In: Rinker HB (ed) Lowman ED. Elsevier Academic Press, Forest canopies, pp 3-23

Nakamura T, Hattori K, Ishida TA, Sato H, Kimura MT (2008) Population dynamics of leafminers on a deciduous oak Quercus dentata. Acta Oecol 34:259-265

Nakamura T, Kimura MT (2009) Weak parasitoid-mediated apparent competition between two Phyllonorycter (Lepidoptera: Gracillariidae) leaf miner species on a deciduous oak Quercus dentata. Entomol Science 12:227-231

Nason JD (2002) La estructura genética de las poblaciones de árboles. In: Guariguata MR, Kattan GH (eds) Ecología y Conservación de los Bosques Neotropicales. Costa Rica, Ediciones LUR, pp 299-328

Nazemi J, Talebi AA, Sadeghi SE, Melika G, Lozan A (2008) Species richness oak wasps (Hymenoptera: Cynipidae) and identification of associated inquilines and parasitoids on two oak species in western Iran. Norw J Zool 4:189-202

Niemelä J, Kotze DJ, Venn S, Penev L, Stoyanov I, Spence J, Hartley D, Montes de Oca E (2002) Carabid beetle assemblages (Coleoptera, Carcabidae) across urban-rural gradients: an international comparison. Landscape Ecol 17:387-401

Nigel R, Hughes L (2004) Species diversity and structure of phytophagous beetle assemblages along a latitudinal gradient predicting the potential impacts of climate change. Ecol Entomol 29:527-542

Niinemets U, Kull K (2003) Leaf structure vs. nutrient relationships vary soil conditions in temperate shrubs and trees. Acta Oecol 24:209-219

Nixon KC (1993) Infrageneric classification of Quercus (Fagaceae) and typification of sectional names. Ann Sci For 50(supplement 1):25-34

Novotny V, Basset Y, Miller SE, Weiblens GD, Bremerk B, Cizek L, Drozod P (2002) Low host specificity of herbivorous insects in a tropical forest. Nature 416:841-843

Novotny V, Basset Y (2005) Review-host specificity of insect herbivores in tropical forest. Proc Roy Soc B: Biol Sci 272:1083-1090

Novotny V, Drozd P, Miller SE, Kulfan M, Janda M, Basset Y, Weiblens GD (2006) Why are there so many species of herbivorous insects in tropical rainforest. Science 313:1115-1118

Osier TL, Hwang S, Lindroth RL (2000) Within-and between-year variation in early season phytochemestry of quaking aspen (Populus tremuloides Michx.) clones. Biochem Syst Ecol 28:197-208

Ozanne CMP, Hambler C, Foggo A, Speigth MR (1997) The significance of edge effects in the management of forest for invertebrate diversity. In: Stork NE, Adis J, Didham RK (eds) Canopy Arthropods. Chapman and Hall, London, pp $534-550$
Ozanne CMP, Speight MR, Hambler C, Evans HF (2000) Isolated trees and forest patches: patterns in canopy arthropod abundance and diversity in Pinus sylvestris (Scot Pine). For Ecol Manage 137:53-63

Ozanne CMP, Anhuf D, Boulter SL, Keller M, Kitching RL, Körner C, Meinzer FC, Mitchell AW, Nakashizukada T, Silva Dias PL, Stork NE, Wrigth SJ, Yoshimura M (2003) Biodiversity meets the atmosphere: a global view of forest canopies. Science 301:183-186

Palacios-Vargas JG, Iglesias R, Castaño-Meneses G (2003) Mites from Mexican canopies. Insect Sci Appl 23:287-292

Parker GC (1995) Structure and microclimate of forest canopies. In: Lowman LM, Nadkarni NM (eds) Forest Canopies. Academic Press, New York, pp 73-106

Parker JD, Burkepile DE, Hay ME (2006) Opposing effects on native and exotic herbivores on plant invasions. Science 311:1459-1461

Peeters PJ, Read J, Sanson GD (2001) Variation in the guild composition herbivorous insect assemblages among co-occurring plant species. Austral Ecol 26:385-399

Pennings SC, Silliman BR (2005) Linking biogeography and community ecology: latitudinal variation in plant-herbivore interactions strength. Ecology 86:2310-2319

Peñaloza-Ramírez JM, González-Rodríguez A, Mendoza-Cuenca L, Caron H, Oyama K (2010) Interspecific gene flow a multispecies oak hybrid zone in the Sierra Tarahumara of Mexico. Ann Bot 105:389-399

Polis GA, Holt RD (1992) Intraguild predation: the dynamics of complex trophic interactions. Trends Ecol Evol 7:151-154

Poulsen BO (2002) Avian richness and abundance in temperate Danish forests: tree variables important to birds and their conservation. Biodivers Conserv 11:1551-1566

Preszler RW, Boecklen WJ (1994) A tree-trophic-level analysis of the effects of plants hybridization on a leaf-mining moth. Oecologia 100:66-73

Price PW, Bouton CE, Gross P, McPheron BA, Thompson JN, Weis AE (1980) Interactions among three trophic levels: influence of plants on interactions between insect herbivores and natural enemies. Ann Rev Ecol Syst 11:41-65

Price PW, Abrahamson WG, Hunter MD, Melika G (2004) Using gall wasps on oaks to test broad ecological concepts. Conserv Biol 18:1405-1416

Redak RA (2000) Arthropods and multispecies habitat conservation plans: are we missing something? Environ Manage 26:97-107

Reitz SR, Trumble JT (2002) Competitive displacement among insects and arachnids 1. Ann Rev Entomol 47:435-465

Ricklefs RE (2008) Foliage chemistry and the distribution of Lepidoptera larvae on broad-leaved trees in southern Ontario. Oecologia 157:53-67

Rieseberg LH (1995) The role of hybridization in evolution: old wine in new skins. Am J Bot 82:944-953

Rinker HB, Lowman MD (2004) Insect herbivory in tropical forest. In: Lowman MD, Rinker HB (eds) Forest canopies. Elsevier/Academic Press, San Diego, CA., pp 359-386

Romero GQ, Gonçalves-Souza T, Vieira C, Koricheva J (2014) Ecosystem engineering effects on species diversity across ecosystems: a meta-analysis. Biol Rev. doi:10.1111/brv.12138

Rosenheim JA, Wilhoit LR, Armer CA (1993) Influence of intraguild predation among generalist insect predators on the suppression of an herbivore population. Oecologia 96:439-449

Roslin T, Gripenberg S, Salminen JP, Karonen M, O' Hara RB, Pihlaja K, Pulkkinen P (2006) Seeing the tres for the leaves-oaks as mosaics for a host specific moth. Oikos 113:106-120

Rzedowski J (1978) Vegetación de México. Limusa, México

Salminen J, Roslin T, Karonen M, Sinkkonen J, Pihlaja K, Pulkkinen P (2004) Seasonal variation in the content of hidrolizable tannins, flavonoid glycosides, and proanthocyanidins in oak leaves. J Chem Ecol 30:1693-1711

Sanchez V, Cambra RA, Nieves-Aldrey JL, Medianero E (2013) Parasitoides asociados a cecidas inducidas por avispas Cynipidae (Hymenoptera) en plantas del género Quercus (Fagaceae) en Panamá. Scientia 23:25-56

Schädler M, Jung G, Auge H, Brandl R (2003) Does the Fretwell-Oksanen model apply to invertebrates? Oikos 100:203-207

Schönrogge K, Begg T, Stone GN (2013) Native birds and alien insects: spatial density dependence in songbird predation of invading oak gall wasps. PLoS One 8(1), e53959. doi:10.1371/journal.pone.0053959

Schowalter TD (1995) Canopy communities in relation to forest age and alternative harvest practices in western Oregon. For Ecol Manage 78:115-125 Schweitzer JA, Madritch MD, Bailey JK, LeRoy CJ, Fischer GD, Rehill BJ, Lindroth RL, Whitham T (2008) From genes to ecosystems: the genetic basis of 
condensed tannins and their role in nutrient regulation in a Populus model system. Ecosystems 11:1005-1020

Şen I, Gök A (2009) Leaf beetle communities (Coleopetera: Chrysomelidae) of two mixed ecosystems dominated by pine-oak-hawthorn in Sparta province, Turkey. Anna Zol Fen 46:217-232

Shea K, Chesson P (2002) Community ecology theory as a framework for biological invasions. Trends Ecol Evol 17:170-176

Shuster SM, Lonsdorf EV, Wimp GM, Bailey JK, Whitham TG (2006) Community heritability measures the evolutionary consequences of indirect genetic effects on community structure. Evolution 60:991-1003

Siemann E, Tilman D, Haarstad J, Ritchie M (1998) Experimental test of the dependence of arthropod diversity on plant diversity. Am Nat 152:738-750

Simmon U, Linsenmair KE (2001) Arthropods in tropical oaks: differences in their spatial distributions within tree crows. Plant Ecol 153:179-191

Simon M, Hilker M (2003) Herbivores and pathogens on willow: do they affect each other? Agric For Entomol 5:275-284

Sobek S, Kampichler C, Weigmann G (2008) Oribatid mites (Acari: Oribatida) in the canopy of a Central European mixed forest: species richness and species similarity between tree species and habitat types. In: Floren A, Schmidl J (eds) Canopy arthropod research in Europe. Basic and applied studies from the high frontier. Bioform Entomology, Nuremberg, pp 339-354

Sobek S, Steffan-Dewenter I, Scherber C, Tschamtke T (2009) Spatio temporal changes of beetle communities across a tree diversity gradient. Divers Distrib 15:660-670

Southwell CJ, Caims SC, Pople AR, Delaney R (1999) Gradient analysis of macropod distribution in open forest and woodland of eastern Australia. Aust J Ecol 24:132-143

Southwood TRE, Moran VC, Kennedy CEJ (1982) The richness, abundance and biomass of the arthropod communities on trees. J Anim Ecol 51:635-649

Southwood TRE, Wint GRW, Kennedy CEJ, Greenwood SR (2004) Seasonality abundance, species richness and specificity of the phytophagous guild of insects on oak (Quercus) canopies. Eur J Entomol 101:43-50

Southwood TRE, Wint GRW, Kennedy CEJ, Greenwood SR (2005) The composition of the arthropod fauna of the canopies of some species of oak (Quercus). Eur J Entomol 102:65-72

Spellenberg R (1995) On the hybrid nature of Quercus basaseachicensis (Fagaceae, sect. Quercus). Sida 16:427-434

Stachowicz JJ (2001) Mutualism, facilitation, and the structure of ecological communities. BioScience 51:235-246

Stout MJ, Thaler JS, Thomma BPHJ (2006) Plant-mediated interactions between pathogenic microorganisms and herbivorous arthropods. Annu Rev Entomol 51:663-689

Stork NE, Hammond PM (1997) Sampling arthropods from tree-crowns by fogging with knockdown insecticides: lessons from studies of oak tree beetle assemblages in Richmond Park (UK). In: Stork NE, Adis J, Didham PK (eds) Canopy Arthropods. Chapman and Hall, London, pp 3-26

Stork NE, Hammond PM (2013) Species richness and temporal partitioning in the beetle fauna of oak trees (Quercus robur L.) in Richmond Park, UK. Insect Conserv Diver 6:67-81

Stork NE (2007) Australian tropical forest canopy crane: new tools for new frontiers. Austral Ecol 32:4-9

Stork NE, Grimbacher PS, Storer S, Oberprieler RG, Reid C, Slipinski SA (2008) What determines whether a species of insect is described? Evidence from a study of tropical forest beetles. Insect Conserv Diver 1:114-119

Strauss SY (1994) Levels of herbivory and parasitism in host hybrid zones. Trends Ecol Evol 9:209-214

Strong DR, Lawton JH, Southwood RS (1984) Insects on plants. Community patterns and mechanisms. Harvard University Press, Cambridge, Massachusetts

Styrsky JD, Eubanks MD (2007) Ecological consequences of interactions between ants and honeydew-producing insects. P Roy Soc B-Biol Sci 274:151-164

Summerville KS, Crist TO (2002) Effects of timber harvest on forest Lepidoptera: community, guild, and species responses. Ecol Appl 12:820-835

Summerville KS, Crist TO (2003) Determinants of lepidopteran species diversity and composition in eastern deciduos forest: roles of season, region and patch size. Oikos 100:134-148

Summerville KS, Boulware MJ, Veech JA, Crist TO (2003a) Spatial variation in species diversity and composition of forest Lepidoptera in eastern deciduous forest of North America. Conserv Biol 17:1045-1057

Summerville KS, Crist TO, Kahan JK, Gering JC (2003b) Community structure arboreal caterpillars within and among four tree species of the eastern deciduous forest. Ecol Entomol 28:747-757
Sutherland WJ (2006) Ecological census techniques: a handbook. Cambridge University Press, Cambridge

Sutton SL (2001) Alice grows up: science in transition from Wonderland to Reality. Plant Ecol 153:13-21

Tack AJ, Ovaskainen O, Pulkkinen P, Roslin T (2010) Spatial location dominates over host plant genotype in structuring an herbivore community. Ecology 91:2660-2672

Tack AJ, Gripenberg S, Roslin T (2012) Cross-kingdom interactions matter: fungal-mediated interactions structure an insect community on oak. Ecol Lett 15:177-185

Tallamy DW (2004) Do alien plants reduce insect biomass? Conserv Biol 18:1689-1692

Tews J, Brose U, Grimm V, Tielbörger K, Whichmann MC, Schwager M, Jeltsch F (2004) Animal species diversity driven by habitat heterogeneity/diversity: the importance of keystone structure. J Biogeogr 31:79-92

Thomas CD, Ng D, Singer MC, Mallet JLB, Parmesan C, Billington HL (1987) Incorporation of a European weed into the diet of a North American herbivore. Evolution 41:892-901

Tovar-Sánchez E, Cano-Santana Z, Oyama K (2003) Canopy arthropod communities on Mexican oaks at sites with different disturbance regimes. Biol Conserv 115:79-87

Tovar-Sánchez E, Oyama K (2004) Natural hybridization and hybrid zones between Quercus crassifolia and Quercus crassipes (Fagaceae) in Mexico: morphological and molecular evidence. Am J Bot 91:1352-1363

Tovar-Sánchez E, Oyama K (2006a) Community structure of canopy arthropods associated in Quercus crassifolia × Quercus crassipes complex. Oikos 112:370381

Tovar-Sánchez E, Oyama K (2006b) Effect of hybridization of the Quercus crassifolia $\times$ Quercus crassipes complex on the community structure on endophagous insects. Oecologia 147:702-713

Tovar-Sánchez E, Mussali-Galante P, Esteban-Jiménez R, Piñero D, Arias DM, Dorado O, Oyama K (2008) Chloroplast DNA polymorphism reveals geographic structure and introgression in Quercus crassifolia $\times$ Quercus crassipes hybrid complex in Mexico. Botany 86:228-239

Tovar-Sánchez E (2009) Canopy arthropods community within and among oak species in central Mexico. Acta Zool Sin 55:132-144

Tovar-Sánchez E, Valencia-Cuevas L, Castillo-Mendoza E, Mussali-Galante P, PérezRuíz RV, Mendoza A (2013) Association between individual genetic diversity of two oak host species and canopy arthropod community structure. Eur J Forest Res 132:165-179

Tovar-Sánchez E, Martí-Flores E, Valencia-Cuevas L, Mussali-Galante P (2015a) Influence of forest type and host plant genetic relatedness on the canopy arthropod community structure of Quercus crassifolia. Rev Chil Hist Nat 88:7. doi:10.1186/s40693-015-0038-2

Tovar-Sánchez E, Valencia-Cuevas L, Mussali-Galante P, Ramírez-Rodríguez R, Castillo-Mendoza E (2015b) Effect of host-plant genetic diversity on oak canopy community structure in Central Mexico. Rev Chil Hist Nat 88:12. doi:10.1186/s40693-015-0042-6

Townsend CR, Scarsbook MR, Dole S (1997) Quantifying disturbance in streams: alternative measures of disturbance in relation to macroinvertebrate species traits and species richness. J N Am Benthol Soc 16:531-544

Ulyshen MD, Hanula JL (2009) Habitat associations of saproxilic beetles in the southeastern United States: a comparison of forest types, tree species and wood postures. For Ecol Manage 257:653-664

Valencia S (2004) Diversidad del género Quercus (Fagaceae) en México. Bol Soc Bot Mex 7:33-53

Valencia-Cuevas L, Piñero D, Mussali-Galante P, Valencia-Ávalos S, Tovar-Sánchez $E$ (2014) Effect of a red oak species gradient on genetic structure and diversity of Quercus castanea (Fagaceae) in Mexico. Tree Genet Genom 10:641-652

Valencia-Cuevas L, Mussali-Galante P, Piñero D, Castillo-Mendoza E, Rangel-Altamirano G, Tovar-Sánchez E (2015) Hybridization of Quercus castanea (Fagaceae) across a red oak species gradient in Mexico. Plant Syst Evol 301:1085-1097

Vakkari P, Blom A, Rusanen M, Raisio J, Toivonen H (2006) Genetic variability of fragmented stands of pedunculate oak (Quercus robur) in Finland. Genetica 127:231-241

Van Bael SA, Brawn JD, Robinson SK (2003) Birds defend trees from herbivores in a Neotropical forest canopy. Proc Natl Acad Sci U S A 100:8304-8307

van Dam NM, Heil M (2011) Multitrophic interactions below and above ground: en route to the next level. J Ecol 99:77-88

Vellend M, Geber MA (2005) Connections between species diversity and genetic diversity. Ecol Lett 8:767-781 
Wagner DL, Peacock JW, Carter JL, Talley SE (1995) Spring caterpillar fauna of oak and blueberry in a Virginia deciduous forest. Ann Entomol Soc Am 88:416-426

Wang HG, Marquis RJ, Baer CS (2012) Both host plant and ecosystem engineer identity influence leaf-tie impacts on the arthropod community of Quercus. Ecology 93:2186-2197

White PS, Pickett STA (1985) Natural disturbance and patch dynamics: an Introduction. In: Pickett STA, White PS (eds) The ecology of natural disturbance and patch dynamics. Academic Press, Orlando, pp 3-13

Whitham TG (1989) Plant hybrid zones as sink for pests. Science 244:1490-1493

Whitham TG, Morrow PA, Potts BM (1994) Plant hybrid zones as centers of biodiversity: the herbivore community of two endemic Tasmanian eucalypts. Oecologia 97:481-490

Whitham TG, Martinsen GD, Floate KD, Dungey HS, Potts BM, Keim P (1999) Plant hybrid zones affect biodiversity: tools for a genetic-based understanding of community structure. Ecology 80:416-428

Whitham TG, Bailey JK, Scheweitzer JA, Shuster SM, Bangert RK, LeRoy CJ, Lonsdorf EV, Allan GJ, DiFazio SP, Potts BM, Fischer DC, Gehring CA, Lindroth RL, Marks JC, Hart SC, Wimp GM, Wooley SC (2006) A framework for community and ecosystem genetics: form genes to ecosystems. Nature 7:510-523

Whitham TG, Gehring CA, Lamit LJ, Wojtowicz T, Evans LM, Keith AR, Smith DS (2012) Community specificity: life and afterlife effects of genes. Trends Plant Sci 17:271-281

Whittemore AT, Schaal BA (1991) Interespecific gene flow in sympatric oaks. Proc Natl Acad Sci U S A 88:2540-2544

Williams SE, Marsh H, Winter J (2002) Spatial scale, species diversity, and habitat structure: small mammals in Australian tropical rain forest. Ecology 83:1317-1329

Wimp GM, Young WP, Woolbright SA, Martinsen GD, Keim P, Whitham TG (2004) Conserving plant genetic diversity for dependent animal communities. Ecol Lett 7:776-780

Wimp GM, Martinsen GD, Floate KD, Bangert RK, Whitham TG (2005) Plant genetic determinants of arthropod community structure and diversity. Evolution 59:6-169

Wright SJ, Van Schaik CP (1994) Light and the phenology of tropical trees. Am Nat 143:192-199

Wold EN, Marquis RJ (1997) Induced defense in white oak: effects on herbivores and consequences for the plant. Ecology 78:1356-1369

Wymore AS, Keeley AT, Yturralde KM, Schroer ML, Propper CR, Whitham TG (2011) Genes to ecosystems: exploring the frontiers of ecology with one of the smallest biological units. New Phytol 191:19-36

Yarnes CT, Boecklen WJ (2005) Abiotic factors promote plant heterogeneity and influence herbivore performance and mortality in Gambel's oak (Quercus gambelii). Entomol Exp App 114:87-95

Yarnes CT, Boecklen WJ, Salminen J (2008) No simple sun: seasonal variation in tannin phenotypes and leaf-miners in hybrid oaks. Chemoecology 18:39-51

\section{Submit your manuscript to a SpringerOpen ${ }^{\circ}$ journal and benefit from:}

- Convenient online submission

- Rigorous peer review

- Immediate publication on acceptance

- Open access: articles freely available online

- High visibility within the field

- Retaining the copyright to your article

Submit your next manuscript at $>$ springeropen.com 